\title{
OPTIMIZATION MODEL FOR MULTIMODAL TRANSPORTATION NETWORKS BASED ON SUPPLY CHAIN
}

\author{
Paweł SITEK*, Jarosław WIKAREK** \\ Faculty of Electrical Engineering, Automatics and Computer Science \\ Kielce University of Technology, Kielce, Poland \\ *e-mail: sitek@tu.kielce.pl \\ **e-mail: j.wikarek@tu.kielce.pl
}

\begin{abstract}
The article presents the problem of supply chain optimization from the perspective of a multimodal logistics provider and includes a mathematical model of multilevel cost optimization in the form of MILP (Mixed Integer Linear Programming). The costs of production, transport, distribution and environmental protection were adopted as optimization criteria. Timing, volume, capacity and mode of transport were also taken into account. The model was implemented in the LINGO ver.12. The numerical experiments were carried out using sample data to show the possibilities of practical decision support and supply chain optimization.
\end{abstract}

Keywords: supply chain, multimodal logistics, MILP, decision support, optimization.

\section{1}

\section{Introduction}

A supply chain is a concept in the area of science and practice that has been strongly developing since the ' 80 s of the last century. Numerous definitions describe the term, and a supply chain reference model has also been designed ([6], [19] and [20]). A supply chain is commonly seen as a collection of various types of companies (raw materials, production, trade, logistics, etc.) working together to improve the flow of products, information and finance. As the words in the term indicate, it is a combination of the chain's individual links in the process of supplying products (material and services) to the market.

The idea of the supply chain dates back to the early ' 80 s of the past century when it was used as an alternative way to assess the relationship between suppliers and customers in the market previously perceived as an arena of ongoing hostilities and taking advantage of the position in the market for benefits and synergy effect.

Initially, a supply chain was a remedy adopted for reducing a company's, supplier's and customer's inventory levels. Currently, attention is being drawn to integration and synchronization of activities within the supply chain, and its automation through IT solutions and multimodal environments.

Supply-chain problems fall into three categories:

- supply-chain infrastructure (network) design and strategy,

- supply-chain planning,
- supply-chain operations and execution.

The first two categories are essentially offline activities associated with establishing the best way to configure and manage the supply-chain network. The third category involves decisions on how to operate the network to choose best response to the external conditions faced by the supply chain (online decision).

The article presents the problem of outsourcing logistics management in supply chain with multimodal network environment and a mathematical model of supply chain optimization in multimodal environment as an integer linear programming problem [12]. This model can be the basis for the decision support in the supply chain management.

The application of the model will allow answering many decision questions such as: How to realize customers' orders at the best price? How will they look at the time of delivery? Which distributors will take part in the supply? Do distributors have sufficient capacity to carry out the orders? What is the level of utilization of capacity distributors? There can be many more of such questions.

As you can see, the results of the optimization of the presented model can be the basis for the decision support (both offline and online).

The complexity and flexibility of the presented model as well as the manner of its implementation are the main achievements and contributions of the article. An additional achievement is the formulation of the model in the form of integer linear programming, which facilitates its use in the practical aspects. 


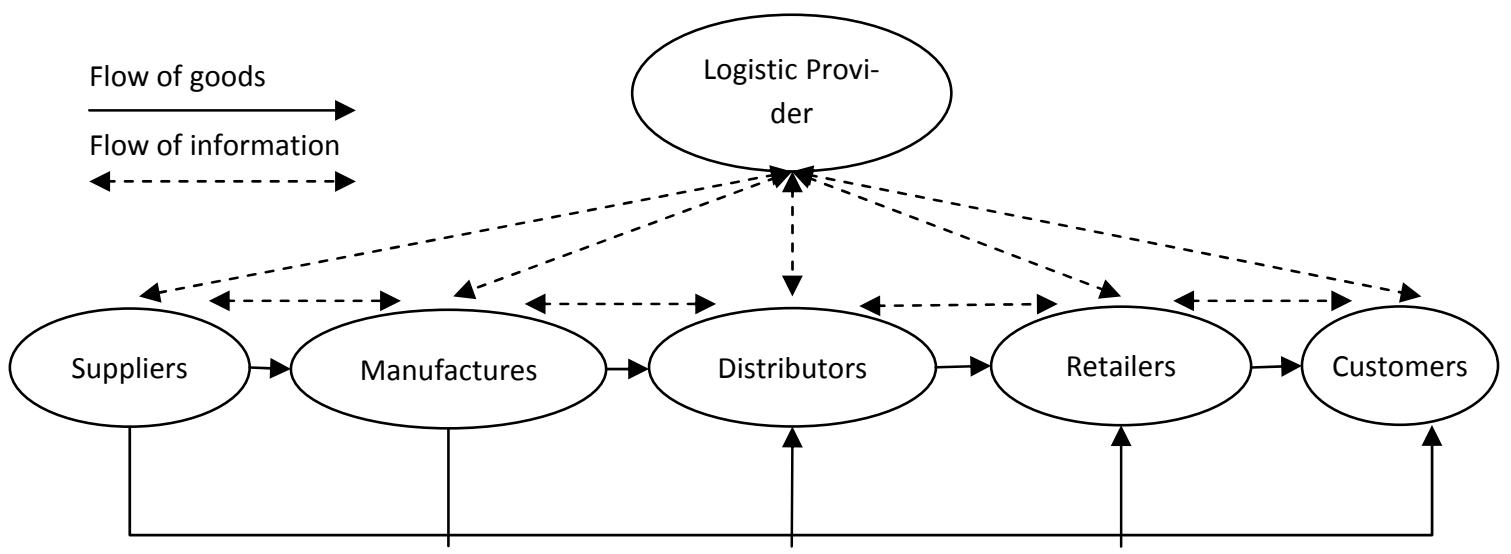

Figure 1. The chart of the supply chain with logistics services outsourced to a logistic provider (source: own work)

This is due to the availability of multiple environments solving this class of models like LINGO, CPLEX.

Very interesting is also the proposal to introduce a new class of decision variables at the implementing level. These variables allow making a deeper analysis of the obtained solutions being transparent to the model, not complicating it further.

\section{Supply Chain Management}

The aim of supply chain management (SCM) is to increase sales, reduce costs and take full advantage of business assets by improving interaction and communication between all the actors forming the chain. The supply chain management is a decision process that not only integrates all of its participants but also helps to coordinate the basic flows: products/services, information and funds. Changes in the global economy and the increasing globalization lead to the widespread use of IT tools, which enable continuous, real-time communication between the supply chain links. One of the objectives is to optimize logistics and entrust it to specialized companies.

This trend contributed to the development of logistics outsourced operators known as 3PL, 4PL, or 5PL. The term 3PL (Third Party Logistics) refers to the use of external companies and organizations to carry out logistic functions that can involve the entire logistics process or its selected features. The company offers and provides 3PL services using its own means of transport, warehouses, equipment and other necessary resources, and acts as a "third party" between a producer and a customer. The resulting model with the supply chain logistics services outsourced to specialized 3LP companies is shown in Fig. 1. This kind of cooperation is frequently referred to as the logistics alliance.

4PL (Fourth Party Logistics) is a certain evolution of the 3PL concept to provide greater flexibility and adaptation to the needs of the client. 4PL companies and organizations operate primarily by managing the information flow within the entire supply chain. A 4PL coordinates logistics processes along the whole length of the chain (from raw materials to end-buyers) not being limited only to the selected segment as is the case with a 3PL. The 4PL model enables the 3PL operator to become a coordinator and integrator of the flows, not just an operator of physical movement of goods. Very often, its subcontractors are 3PL or even 2PL (Second Party Logistics) operators, i.e., transport companies and warehouses. A company that uses the services of a $4 \mathrm{PL}$ provider is in contact with only one operator who manages and integrates all types of resources and oversees the entire functionality across the supply chain. 4PL providers, having a complete picture of the supply chain and large IT capabilities may offer optimization and decision support advisory services. Further development of logistics outsourcing resulted in the creation of 5LP model (Fifth Party Logistics) - providers of integrated logistics services that can design and implement flexible and networked supply chains with multimodal environments to cater to the needs of all participants (manufacturers, suppliers, carriers and end users) [18]. 


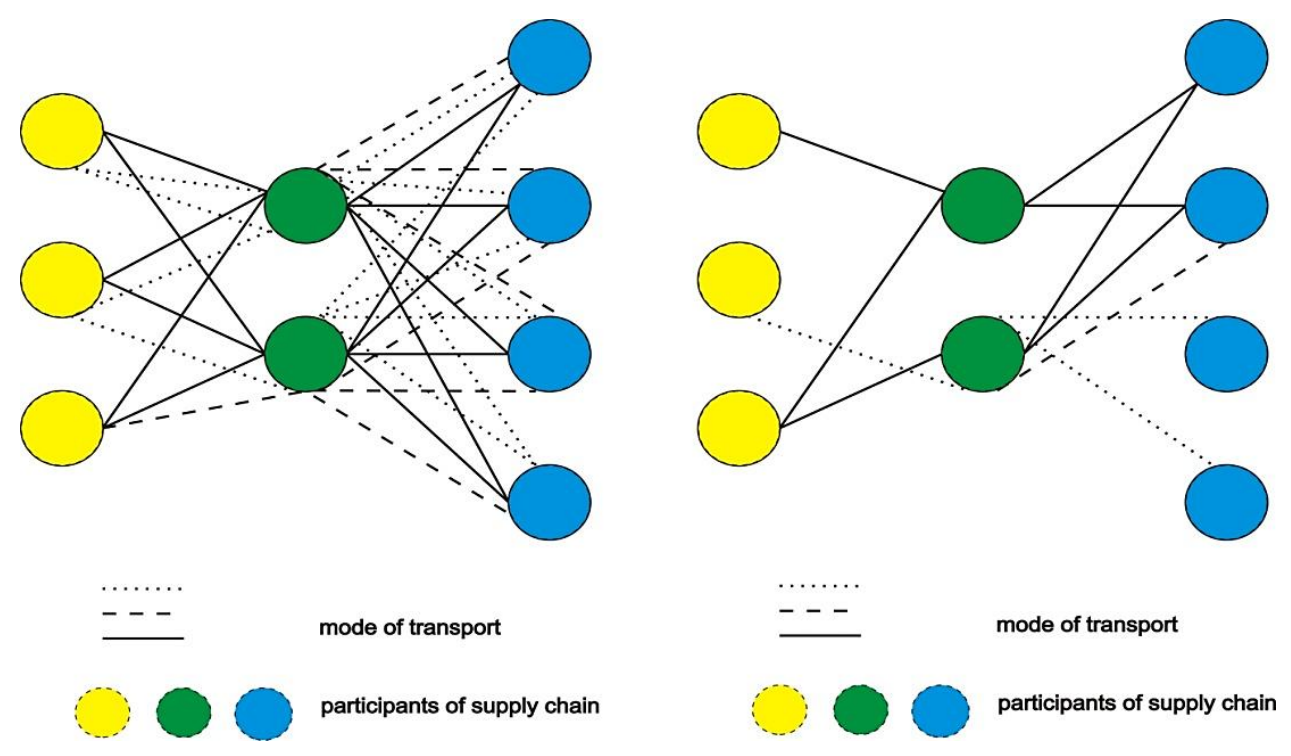

Figure 2. The part of supply chain network including multimodal transport (source: own work)

\section{3}

\section{Mode of transport in Supply Chain}

Many logistic providers have or use multimodal transportation systems. Transportation system is multimodal when the infrastructure supports various transportation modes, such as truck, rail, air, and ocean/river navigation, and carriers operating and offering transportation services on these modes. International multimodal transport is a logistic concept that covers the movements of goods from a supplier to a receiver under the responsibility of a single transport operator. It represents the flow of goods, where at least on one part of the transport chain, two different modern mode of transport are involved at the same time.

Currently, most of the logistics is or uses the services of MTO (Multimodal Transport Operator- organizes and is responsible for the whole transport chain on the basis of one multimodal contract).

A model of supply chain network of multimodal transport is shown in Fig. 2. The chart on the left shows all the acceptable modes of transport between the participants in the supply chain. The chart on the right shows the optimal or feasible configuration of the transport for a given set of customer orders.

\section{$4 \quad$ Motivation}

Simultaneously considering the supply chain production, distribution processes in distribution centers and transport-planning problems greatly advances the efficiency of all processes. The literature in the field is vast, so an extensive review of existing research on the topic is extremely helpful in modeling and research. Comprehensive surveys on these problems and their generalizations were published, for example, in [9].

In our approach, we are considering a case of the supply chain where:

- the shared information process [9] in the supply chain consists of resources (capacity, versatility, costs), inventory (capacity, versatility, costs, time), production (capacity, versatility, costs), product (volume), transport (cost, mode, time), demand, etc.,

- the transport is multimodal (several modes of transport, limited number of means of transport for each mode),

- different products are combined in one batch of transport,

- the cost of supplies is presented in the form of a function (in this approach linear function of fixed and variable costs) ([11], [15], [14], [10] and [16]),

- different decision levels are considered simultaneously,

- the environmental aspects of use of transport modes (depend on the use of fossil fuels and carbondioxide emissions etc.). 


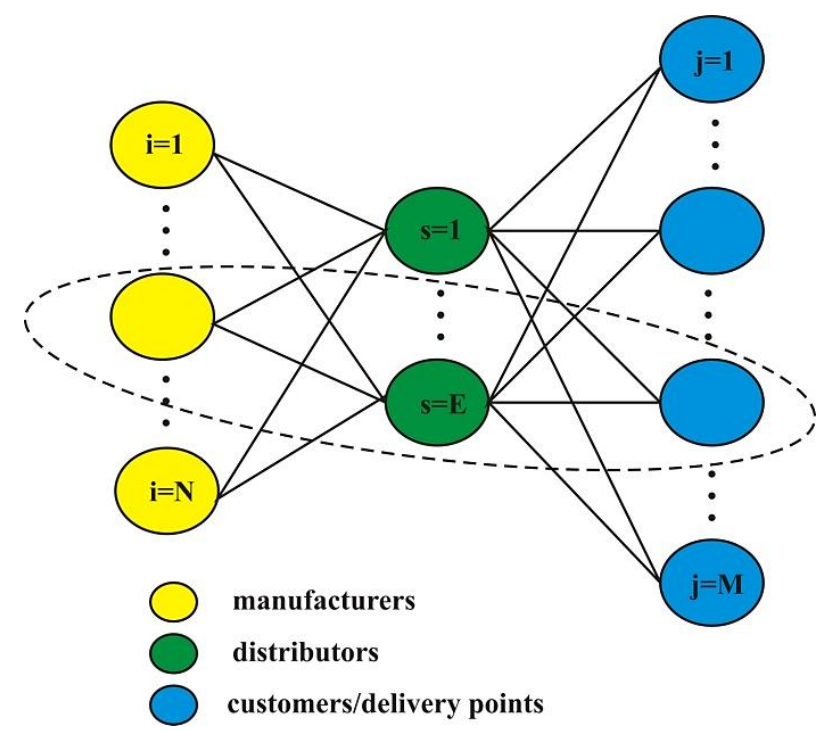

Figure 3. The part of the supply chain network with marked indices of individual participants (elements). Dashed line marks one of the possible routes of delivery. Relationships between the participants are multimodal (source: own work)

Therefore, the motivation behind this work [9] is to suggest an approach to decision support in the supply chain that can provide decision support at various levels of decision-making, taking into account the many types of constraints (time, capacity, environment etc.). The proposed approach will be a demanddriven model. The aim of this paper is to design and implement the model that can become the basis for making optimal decisions at different levels of supply chain management. The proposed solution will also enable a comprehensive examination of the impact on cost and performance of various parameters of the shared information. An important feature of the proposed model is its multimodality. It occurs at different levels of detail. On the one hand, the model includes multimodal transport and on the other constraints of the model are different types (modes). There are resource constraints, time constraints, capacity constraints, space and environment constraints.

\section{$5 \quad$ Mathematical model}

For the supply chain network model (see Fig. 3) with multimodal transport (see Fig. 2), an optimization model was proposed, designed from a perspective of logistic /MTO providers. The mathematical optimization model was formulated as an integer linear programming problem ([17], [25]) with the minimization of costs (1) under constraints (2)..(24). Indices, parameters and decision variables in the model together with their descriptions are provided in Table 1. The proposed optimization model is a cost model that takes into account two other types of parameters, i.e., the spatial parameters (are/ volume occupied by the product, specified by the distributor) and time (duration of delivery and service by distributor, etc.). The position of each parameter against the subsequent links of the supply chain is shown in Fig. 4. The objective function (1) defines the aggregate costs of the entire chain and consists of five elements. The first is the fixed costs associated with the operation of the distributor involved in the delivery (e.g. distribution center, warehouse, etc.). The second part sets out the environmental costs of using various means of transport. They are dependent on the one hand the number of courses the means of transport, the other from the environmental levy, which may depend on the use of fossil fuels and carbon-dioxide emissions.

The third component determines the cost of supply from the manufacturer to the distributor. Another component is responsible for the costs of supply from the distributor to the end user (the store, the individual client, etc.). The last component of the objective function determines the cost of manufacturing the product by the given manufacturer. The model was developed with the constraints (2)..(24).

Constraint (2) specifies that all deliveries of product $\mathrm{k}$ produced by the manufacturer $\mathrm{i}$ and delivered to all distributors s using mode of transport $\mathrm{d}$ do not exceed the manufacturer's production capacity. 


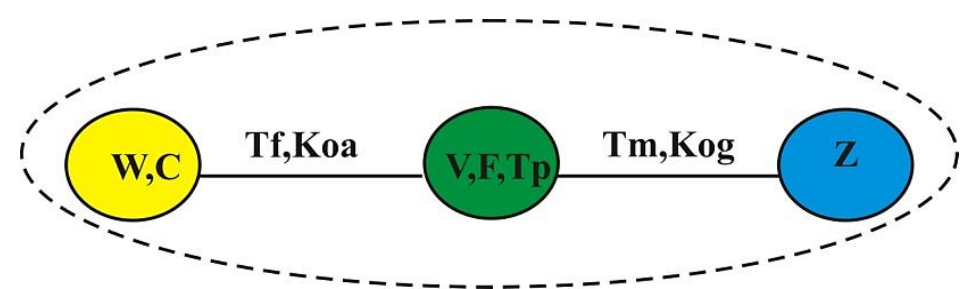

Figure 4. The selected path of the supply chain along with the parameters that describe the individual elements and their dependencies

(source: own work)

Table 1. Summary indices, parameters and decision variables of the mathematical optimization model (source: own work)

\begin{tabular}{|c|c|c|c|}
\hline \multicolumn{4}{|l|}{ Indices } \\
\hline Symbol & Description & Symbol & Description \\
\hline $\mathrm{k}$ & product type $(\mathrm{k}=1 . . \mathrm{O})$ & $\mathrm{N}$ & number of manufacturers/factories \\
\hline $\mathrm{j}$ & delivery point/customer/city $(\mathrm{j}=1 . . \mathrm{M})$ & M & number of delivery points/customers \\
\hline $\mathrm{i}$ & manufacturer/factory $(\mathrm{i}=1 . . \mathrm{N})$ & $\mathrm{E}$ & number of distributors \\
\hline $\mathrm{s}$ & distributor /distribution center $(\mathrm{s}=1 . . \mathrm{E})$ & $\mathrm{O}$ & number of product types \\
\hline $\mathrm{d}$ & mode of transport $(\mathrm{d}=1 . . \mathrm{L})$ & $\mathrm{L}$ & number of mode of transport \\
\hline \multicolumn{4}{|c|}{ Input parameters } \\
\hline Symbol & \multicolumn{3}{|c|}{ Description } \\
\hline $\mathrm{F}_{\mathrm{S}}$ & \multicolumn{3}{|c|}{ the fixed cost of distributor/distribution center $\mathrm{s}(\mathrm{s}=1 . . \mathrm{E})$} \\
\hline $\mathrm{P}_{\mathrm{k}}$ & \multicolumn{3}{|c|}{ the area/volume occupied by product $\mathrm{k}(\mathrm{k}=1 . . \mathrm{O})$} \\
\hline $\mathrm{V}_{\mathrm{s}}$ & \multicolumn{3}{|c|}{ distributor s maximum capacity/volume $(\mathrm{s}=1 . . \mathrm{E})$} \\
\hline $\mathrm{W}_{\mathrm{i}, \mathrm{k}}$ & \multicolumn{3}{|c|}{ production capacity at factory $\mathrm{i}$ for product $\mathrm{k}(\mathrm{i}=1 . . \mathrm{N})(\mathrm{k}=1 . . \mathrm{O})$} \\
\hline $\mathrm{C}_{\mathrm{i}, \mathrm{k}}$ & \multicolumn{3}{|c|}{ the cost of product $\mathrm{k}$ at factory $\mathrm{i}(\mathrm{i}=1 . . \mathrm{N})(\mathrm{k}=1 . . \mathrm{O})$} \\
\hline $\mathrm{R}_{\mathrm{s}, \mathrm{k}}$ & \multicolumn{3}{|c|}{ if distributor $\mathrm{s}(\mathrm{s}=1 . . \mathrm{E})$ can deliver product $\mathrm{k}(\mathrm{k}=1 . . \mathrm{O})$ then $\mathrm{R}_{\mathrm{sk}}=1$, otherwise $\mathrm{R}_{\mathrm{sk}}=0$} \\
\hline $\mathrm{Tp}_{\mathrm{s}, \mathrm{k}}$ & \multicolumn{3}{|c|}{ the time needed for distributor $\mathrm{s}(\mathrm{s}=1 . . \mathrm{E})$ to prepare the shipment of product $\mathrm{k}(\mathrm{k}=1 . . \mathrm{O})$} \\
\hline $\mathrm{Tc}_{\mathrm{i}, \mathrm{k}}$ & \multicolumn{3}{|c|}{ the cut-off time of delivery to the delivery point/customer $\mathrm{j}(\mathrm{j}=1 . . \mathrm{M})$ of product $\mathrm{k}(\mathrm{k}=1 . . \mathrm{O})$} \\
\hline$Z_{\mathrm{j}, \mathrm{k}}$ & \multicolumn{3}{|c|}{ customer demand/order $\mathrm{j}(\mathrm{j}=1 . . \mathrm{M})$ for product $\mathrm{k}(\mathrm{k}=1 . . \mathrm{O})$} \\
\hline $\mathrm{Zt}_{\mathrm{d}}$ & \multicolumn{3}{|c|}{ the number of transport units using mode of transport $d(d=1 . . L)$} \\
\hline $\mathrm{Pt}_{\mathrm{d}}$ & \multicolumn{3}{|c|}{ the capacity of transport unit using mode of transport $\mathrm{d}(\mathrm{d}=1 . . \mathrm{L})$} \\
\hline $\mathrm{Tf}_{\mathrm{i}, \mathrm{s}, \mathrm{d}}$ & \multicolumn{3}{|c|}{$\begin{array}{l}\text { the time of delivery from manufacturer } \mathrm{i} \text { to distributor } \mathrm{s} \text { using mode of transport } \mathrm{d}(\mathrm{I}=1 . . \mathrm{N}) \\
(\mathrm{s}=1 . . \mathrm{E})(\mathrm{d}=1 . . \mathrm{L})\end{array}$} \\
\hline $\mathrm{K} 1_{\mathrm{i}, \mathrm{s}, \mathrm{k}, \mathrm{d}}$ & \multicolumn{3}{|c|}{$\begin{array}{l}\text { the variable cost of delivery of product } \mathrm{k} \text { from manufacturer } \mathrm{i} \text { to distributor } \mathrm{s} \text { using mode of transport } \mathrm{d} \\
(\mathrm{d}=1 . . \mathrm{L})(\mathrm{i}=1 . . \mathrm{N})(\mathrm{s}=1 . . \mathrm{E})(\mathrm{k}=1 . . \mathrm{O})\end{array}$} \\
\hline $\mathrm{R} 1_{\mathrm{i}, \mathrm{s}, \mathrm{d}}$ & \multicolumn{3}{|c|}{$\begin{array}{l}\text { if manufacturer } \mathrm{i} \text { can deliver to distributor } \mathrm{s} \text { using mode of transport } \mathrm{d} \text { then } \mathrm{R} 1_{\text {isd }}=1 \text {, otherwise } \mathrm{R} 1_{\text {isd }}=0 \\
(\mathrm{~d}=1 . . \mathrm{L})(\mathrm{s}=1 . . \mathrm{E})(\mathrm{i}=1 . . \mathrm{N})\end{array}$} \\
\hline $\mathrm{A}_{\mathrm{i}, \mathrm{s}, \mathrm{d}}$ & \multicolumn{3}{|c|}{$\begin{array}{l}\text { the fixed cost of delivery from manufacturer } i \text { to distributor } s \text { using mode of transport } d(d=1 . . L)(i=1 . . N) \\
(s=1 . . \mathrm{E})\end{array}$} \\
\hline $\mathrm{Koa}_{\mathrm{i}, \mathrm{s}, \mathrm{d}}$ & \multicolumn{3}{|c|}{$\begin{array}{l}\text { the total cost of delivery from manufacturer } i \text { to distributor } s \text { using mode of transport } d(d=1 . . L) \\
(i=1 . . N)(s=1 . . \mathrm{E})\end{array}$} \\
\hline $\operatorname{Tm}_{\mathrm{s}, \mathrm{j}, \mathrm{d}}$ & \multicolumn{3}{|c|}{$\begin{array}{l}\text { the time of delivery from distributor } \mathrm{s} \text { to customer } \mathrm{j} \text { using mode of transport } \mathrm{d}(\mathrm{d}=1 . . \mathrm{L}) \\
(\mathrm{s}=1 . . \mathrm{E})(\mathrm{j}=1 . . \mathrm{M})\end{array}$} \\
\hline $\mathrm{K} 2_{\mathrm{s}, \mathrm{j}, \mathrm{k}, \mathrm{d}}$ & \multicolumn{3}{|c|}{$\begin{array}{l}\text { the variable cost of delivery of product } \mathrm{k} \text { from distributor } \mathrm{s} \text { to customer } \mathrm{j} \text { using mode of transport } \mathrm{d} \\
(\mathrm{d}=1 . . \mathrm{L})(\mathrm{s}=1 . . \mathrm{E})(\mathrm{k}=1 . . \mathrm{O})(\mathrm{j}=1 . . \mathrm{M})\end{array}$} \\
\hline $\mathrm{R} 2_{\text {sjd }}$ & \multicolumn{3}{|c|}{$\begin{array}{l}\text { if distributor s can deliver to customer } \mathrm{j} \text { using mode of transport } \mathrm{d} \text { then } \mathrm{R} 2_{\mathrm{sjd}}=1 \text {, otherwise } \mathrm{R} 2_{\mathrm{s}, \mathrm{j}, \mathrm{d}}=0 \\
(\mathrm{~d}=1 . . \mathrm{L})(\mathrm{s}=1 . . \mathrm{E})(\mathrm{j}=1 . . \mathrm{M})\end{array}$} \\
\hline $\mathrm{G}_{\mathrm{s}, \mathrm{j}, \mathrm{d}}$ & \multicolumn{3}{|c|}{$\begin{array}{l}\text { the fixed cost of delivery from distributor } s \text { to customer } \mathrm{j} \text { using mode of transport } \mathrm{d}(\mathrm{s}=1 . . \mathrm{E}) \\
(\mathrm{j}=1 . . \mathrm{M})(\mathrm{k}=1 . . \mathrm{O})\end{array}$} \\
\hline $\operatorname{Kog}_{s, j, d}$ & \multicolumn{3}{|c|}{$\begin{array}{l}\text { the total cost of delivery from distributor } s \text { to customer } \mathrm{j} \text { using mode of transport } \mathrm{d}(\mathrm{d}=1 . . \mathrm{L})(\mathrm{s}=1 . . \mathrm{E}) \\
(\mathrm{j}=1 . . \mathrm{M})(\mathrm{k}=1 . . \mathrm{O})\end{array}$} \\
\hline $\mathrm{Od}_{\mathrm{d}}$ & \multicolumn{3}{|c|}{ the environmental cost of using mode of transport $d(d=1 . . L)$} \\
\hline
\end{tabular}


Table 2. Summary indices, parameters and decision variables of the mathematical optimization model (continued)

(source: own work)

\begin{tabular}{|c|l|}
\hline $\begin{array}{c}\text { Sym- } \\
\text { bol }\end{array}$ & \multicolumn{1}{|c|}{ Decision variables } \\
\hline $\mathrm{X}_{\mathrm{i}, \mathrm{s}, \mathrm{d}, \mathrm{d}}$ & Description \\
\hline $\mathrm{Xa}_{\mathrm{i}, \mathrm{s}, \mathrm{d}}$ & $\begin{array}{l}\text { delivery quantity of product } \mathrm{k} \text { from manufacturer i to distributor s using mode of transport } \mathrm{d} \\
\mathrm{Xa}_{\mathrm{i}, \mathrm{s}, \mathrm{d}}=1, \text { otherwise } \mathrm{Xa}_{\mathrm{i}, \mathrm{s}, \mathrm{d}}=0\end{array}$ \\
\hline $\mathrm{Xb}_{\mathrm{i}, \mathrm{s}, \mathrm{d}}$ & the number of courses from manufacturer i to distributor s using mode of transport $\mathrm{d}$ \\
\hline $\mathrm{Y}_{\mathrm{s}, \mathrm{j}, \mathrm{d}, \mathrm{d}}$ & delivery quantity of product $\mathrm{k}$ from distributor $\mathrm{s}$ to customer $\mathrm{j}$ using mode of transport $\mathrm{d}$ \\
\hline $\mathrm{Ya}_{\mathrm{s}, \mathrm{j}, \mathrm{d}}$ & $\begin{array}{l}\text { if delivery is from distributor } \mathrm{s} \text { to customer } \mathrm{j} \text { using mode of transport } \mathrm{d} \text { then } \mathrm{Ya}_{\mathrm{s}, \mathrm{j}, \mathrm{d}}=1 \text {, otherwise } \\
\text { Ya } \mathrm{a}_{\mathrm{s}, \mathrm{j}, \mathrm{d}}=0\end{array}$ \\
\hline $\mathrm{Yb}_{\mathrm{s}, \mathrm{j}, \mathrm{d}}$ & the number of courses from distributor $\mathrm{s}$ to customer $\mathrm{j}$ using mode of transport $\mathrm{d}$ \\
\hline $\mathrm{Tc} \mathrm{c}_{\mathrm{s}}$ & if distributor s participates in deliveries, then $\mathrm{T}_{\mathrm{cs}}=1$, otherwise $\mathrm{T}_{\mathrm{cs}}=0$ \\
\hline $\mathrm{CW}$ & arbitrarily large constant \\
\hline
\end{tabular}

Constraint (3) covers all customer $\mathrm{j}$ demands for product $\mathrm{k}\left(\mathrm{Z}_{\mathrm{j}, \mathrm{k}}\right)$ through the implementation of supply by distributors $\mathrm{s}$ (the values of decision variables $\left.\mathrm{Y}_{\mathrm{i}, \mathrm{s}, \mathrm{k}, \mathrm{d}}\right)$. The constraint was designed to take into account the specificities of the distributors resulting from environmental or technological constraints (i.e., whether the distributor $\mathrm{s}$ can deliver the product $\mathrm{k}$ or not). The balance of each distributor s corresponds to constraint (4). The possibility of delivery in due to its technical capabilities - in the model, in terms of volume /capacity of the distributor's is defined by constraint (5). Constraint (6) ensures the fulfillment of the terms of delivery time. Constraints (7), (8), (9) guarantee deliveries with available transport taken into account. Constraints (10), (11), (12) respectively set values of decision variables based on binary variables $\mathrm{Tc}_{\mathrm{s}}$, $\mathrm{Xa}_{\mathrm{i}, \mathrm{s}, \mathrm{d}}, \mathrm{Ya}_{\mathrm{s}, \mathrm{j}, \mathrm{d}}$. Dependencies (13) and (14) represent the relationship by which total costs are calculated. In general, these may be any linear functions. The remaining constraints (15)...(24) arise from the nature of the model (MIP- mixed integer linear programming).

In this model the cost of supplies Koa (13), Kog (14) is presented in the form of a function. This could be any function with various parameters. In the present version of the model, they are linear functions whose values depend on such supplied products, distance and mode of transport.

The objective function - minimization of costs

$$
\begin{gathered}
\sum_{\mathrm{s}=1}^{\mathrm{E}} \mathrm{F}_{\mathrm{s}} * \mathrm{Tc}_{\mathrm{s}}+\sum_{\mathrm{d}=1}^{\mathrm{L}} \mathrm{Od}_{\mathrm{d}}\left(\sum_{\mathrm{i}=1}^{\mathrm{N}} \sum_{\mathrm{s}=1}^{\mathrm{E}} \mathrm{Xb}_{\mathrm{i}, \mathrm{s}, \mathrm{d}}+\sum_{\mathrm{s}=1}^{\mathrm{E}} \sum_{\mathrm{j}=1}^{\mathrm{M}} \mathrm{Yb}_{\mathrm{j}, \mathrm{s}, \mathrm{d}}\right) \\
+\sum_{\mathrm{i}=1}^{\mathrm{N}} \sum_{\mathrm{s}=1}^{\mathrm{E}} \sum_{\mathrm{d}=1}^{\mathrm{L}} \mathrm{Koa}_{\mathrm{i}, \mathrm{s}, \mathrm{d}}+\sum_{\mathrm{s}=1}^{\mathrm{E}} \sum_{\mathrm{j}=1}^{\mathrm{M}} \sum_{\mathrm{d}=1}^{\mathrm{L}} \mathrm{Kog}_{\mathrm{s}, \mathrm{j}, \mathrm{d}}++\sum_{\mathrm{i}=1}^{\mathrm{N}} \sum_{\mathrm{k}=1}^{\mathrm{O}}\left(\mathrm{C}_{\mathrm{ik}} * \sum_{\mathrm{s}=1}^{\mathrm{E}} \sum_{\mathrm{d}=1}^{\mathrm{L}} \mathrm{X}_{\mathrm{i}, \mathrm{s}, \mathrm{k}, \mathrm{d}}\right)
\end{gathered}
$$

subject to:

$$
\begin{gathered}
\sum_{s=1}^{E} \sum_{d=1}^{L} X_{i, s, k, d} \leq W_{i, k} \text { for } i=1 . . N, k=1 . . O \\
\sum_{s=1}^{E} \sum_{d=1}^{L}\left(Y_{s, j, k, d} * R_{s, k}\right) \geq Z_{j, k} \text { for } j=1 . . M, k=1 . . O \\
\sum_{i=1}^{N} \sum_{d=1}^{L} X_{i, s, k, d}=\sum_{j=1}^{M} \sum_{d=1}^{L} Y_{s, j, k, d} \text { for } s=1 . . E, k=1 . . O \\
\sum_{k=1}^{O}\left(P_{k} * \sum_{i=1}^{N} \sum_{d=1}^{L} X_{i, s, k, d}\right) \leq T c_{s} * V_{s} \text { for } s=1 . . E
\end{gathered}
$$




$$
\begin{aligned}
& X \mathrm{a}_{\mathrm{i}, \mathrm{s}, \mathrm{d}} * \mathrm{Tf}_{\mathrm{i}, \mathrm{s,a}}+\mathrm{Xa}_{\mathrm{i}, \mathrm{s}, \mathrm{d}} * \mathrm{Tp}_{\mathrm{s}, \mathrm{k}}+\mathrm{Ya}_{\mathrm{s}, \mathrm{j}, \mathrm{d}} * \mathrm{Tm}_{\mathrm{s}, \mathrm{j}, \mathrm{d}} \leq \mathrm{Tc}_{\mathrm{j}, \mathrm{k}} \\
& \text { for } \mathrm{i}=1 . . \mathrm{N}, \mathrm{s}=1 . . \mathrm{E}, \mathrm{j}=1 . . \mathrm{M}, \mathrm{k}=1 . . \mathrm{O}, \mathrm{d}=1 . . \mathrm{L} \\
& \mathrm{R}_{\mathrm{i}, \mathrm{s}, \mathrm{d}} * \mathrm{Xb}_{\mathrm{i}, \mathrm{s}, \mathrm{d}} * \mathrm{Pt}_{\mathrm{d}} \geq \mathrm{X}_{\mathrm{i}, \mathrm{s}, \mathrm{k}, \mathrm{d}} * \mathrm{P}_{\mathrm{k}} \text { for } \mathrm{i}=1 . . \mathrm{N}, \mathrm{s}=1 . . \mathrm{E}, \mathrm{k}=1 . . \mathrm{O}, \mathrm{d}=1 . . \mathrm{L} \\
& \mathrm{R} 2_{\mathrm{s}, \mathrm{j}, \mathrm{d}} * \mathrm{Yb}_{\mathrm{s}, \mathrm{j}, \mathrm{d}} * \mathrm{Pt}_{\mathrm{d}} \geq \mathrm{Y}_{\mathrm{s}, \mathrm{j}, \mathrm{k}, \mathrm{d}} * \mathrm{P}_{\mathrm{k}} \text { for } \mathrm{s}=1 . . \mathrm{E}, \mathrm{j}=1 . . \mathrm{M}, \mathrm{k}=1 . . \mathrm{O}, \mathrm{d}=1 . . \mathrm{L} \\
& \sum_{\mathrm{i}=1}^{\mathrm{N}} \sum_{\mathrm{s}=1}^{\mathrm{E}} \mathrm{Xb}_{\mathrm{i}, \mathrm{s}, \mathrm{d}}+\sum_{\mathrm{j}=1}^{\mathrm{M}} \sum_{\mathrm{s}=1}^{\mathrm{E}} \mathrm{Yb}_{\mathrm{j}, \mathrm{s,d}} \leq \mathrm{Zt}_{\mathrm{d}} \text { for } \mathrm{d}=1 . . \mathrm{L} \\
& \sum_{\mathrm{i}=1}^{\mathrm{N}} \sum_{\mathrm{d}=1}^{\mathrm{L}} \mathrm{Xb}_{\mathrm{i}, \mathrm{s}, \mathrm{d}} \leq \mathrm{CW} * \mathrm{Tc}_{\mathrm{s}} \text { for } \mathrm{s}=1 . . \mathrm{E} \\
& \mathrm{Xb}_{\mathrm{i}, \mathrm{s}, \mathrm{d}} \leq \mathrm{CW} * \mathrm{Xa}_{\mathrm{i}, \mathrm{s}, \mathrm{d}} \text { for } \mathrm{i}=1 . . \mathrm{N}, \mathrm{s}=1 . . \mathrm{E}, \mathrm{d}=1 . . \mathrm{L} \\
& \mathrm{Yb}_{\mathrm{s}, \mathrm{j}, \mathrm{d}} \leq \mathrm{CW} \mathrm{W}^{*} \mathrm{Ya}_{\mathrm{s}, \mathrm{j}, \mathrm{d}} \text { for } \mathrm{s}=1 . . \mathrm{E}, \mathrm{j}=1 . . \mathrm{M}, \mathrm{d}=1 . . \mathrm{L} \\
& \mathrm{Koa}_{\mathrm{i}, \mathrm{s}, \mathrm{d}}=\mathrm{A}_{\mathrm{i}, \mathrm{s}, \mathrm{d}} * \mathrm{Xb}_{\mathrm{i}, \mathrm{s}, \mathrm{d}}+\sum_{\mathrm{k}=1}^{\mathrm{O}} \mathrm{K} 1_{\mathrm{i}, \mathrm{s}, \mathrm{k}, \mathrm{d}} * \mathrm{X}_{\mathrm{i}, \mathrm{s}, \mathrm{k}, \mathrm{d}} \text { for } \mathrm{i}=1 . . \mathrm{N}, \mathrm{s}=1 . . \mathrm{E}, \mathrm{d}=1 . . \mathrm{L} \\
& \mathrm{Kog}_{\mathrm{s}, \mathrm{j}, \mathrm{d}}=\mathrm{G}_{\mathrm{s}, \mathrm{j}, \mathrm{d}} * \mathrm{Yb}_{\mathrm{j}, \mathrm{s,d}}+\sum_{\mathrm{k}=1}^{\mathrm{O}} \mathrm{K} 2_{\mathrm{s}, \mathrm{j}, \mathrm{k}, \mathrm{d}} * \mathrm{Y}_{\mathrm{s}, \mathrm{j}, \mathrm{k}, \mathrm{d}} \text { for } \mathrm{s}=1 . . \mathrm{E}, \mathrm{j}=1 . . \mathrm{M}, \mathrm{d}=1 . . \mathrm{L} \\
& \mathrm{X}_{\mathrm{i}, \mathrm{s}, \mathrm{k}, \mathrm{d}} \geq 0 \text { for } \mathrm{i}=1 . . \mathrm{N}, \mathrm{s}=1 . . \mathrm{E}, \mathrm{k}=1 . .0, \mathrm{~d}=1 . . \mathrm{L} \\
& \mathrm{Xb}_{\mathrm{i}, \mathrm{s}, \mathrm{d}} \geq 0 \text { for } \mathrm{i}=1 . . \mathrm{N}, \mathrm{s}=1 . . \mathrm{E}, \mathrm{d}=1 . . \mathrm{L} \\
& \mathrm{Yb}_{\mathrm{s}, \mathrm{j}, \mathrm{d}} \geq 0 \text { for } \mathrm{s}=1 . . \mathrm{E}, \mathrm{j}=2 . . \mathrm{M}, \mathrm{d}=1 . . \mathrm{L} \\
& \mathrm{X}_{\mathrm{i}, \mathrm{s}, \mathrm{k}, \mathrm{d}} \in \mathrm{C} \text { for } \mathrm{i}=1 . . \mathrm{N}, \mathrm{s}=1 . . \mathrm{E}, \mathrm{k}=1 . .0, \mathrm{~d}=1 . . \mathrm{L} \\
& \mathrm{Xb}_{\mathrm{i}, \mathrm{s}, \mathrm{d}} \in \mathrm{C} \text { for } \mathrm{i}=1 . . \mathrm{N}, \mathrm{s}=1 . . \mathrm{E}, \mathrm{d}=1 . . \mathrm{L} \\
& Y_{s, j, k, d} \in C \text { for } s=1 . . E, j=1 . . M, k=1 . .0, d=1 . . L \\
& \mathrm{Yb}_{\mathrm{s}, \mathrm{j}, \mathrm{d}} \in \mathrm{C} \text { for } \mathrm{s}=1 . . \mathrm{E}, \mathrm{j}=1 . . \mathrm{M}, \mathrm{d}=1 . . \mathrm{L} \\
& X a_{i, s, d} \in\{0,1\} \text { for } \mathrm{i}=1 . . \mathrm{N}, \mathrm{s}=1 . . \mathrm{E}, \mathrm{j}=1 . . \mathrm{M}, \mathrm{d}=1 . . \mathrm{L} \\
& \mathrm{Ya}_{\mathrm{s}, \mathrm{j}, \mathrm{d}} \in\{0,1\} \text { for } \mathrm{s}=1 . . \mathrm{E}, \mathrm{j}=1 . . \mathrm{M}, \mathrm{d}=1 . . \mathrm{L} \\
& \mathrm{Tc}_{\mathrm{s}} \in\{0,1\} \text { for } \mathrm{s}=1 . . \mathrm{E}
\end{aligned}
$$

\section{Implementation of the model}

The model was implemented in LINGO environment designed by LINDO Systems [8]. LINGO Optimization Modeling Software is a powerful tool for building and solving mathematical optimization models. The LINGO package provides the language to build optimization models and the editor program including all the necessary features and built-in "solvers" in a single integrated environment. It is designed to model and solve linear, nonlinear, quadratic, integer and stochastic optimization problems. Model implementation is possible in two basic ways. The first way is to enter the model into the LINGO editor in the explicit form, that is, a full function of the objective with all the constraints, parameters, etc. Although this approach is intuitive and consistent with the standard form of linear programming [17], it is not very useful in practice. This is due to the size of models implemented in practice. For the examples presented in "Computational Examples" chapter, the number of decision variables and constraints was 451 and 863, respectively. The other way is to use the LINGO language of mathematical modeling (implicit form), an integral part of the LINGO package, whose basic syntax elements are shown in Table 2. 
Table 2. The set of tables with numerical data for example P1, P2, P3

\begin{tabular}{|l|l|}
\hline \multicolumn{1}{|c|}{ Mathematical nomenclature } & \multicolumn{1}{c|}{ LINGO syntax } \\
\hline Minimum & MIN $=$ \\
\hline$\sum Z_{\mathrm{jkt}}$ & $@$ sum(ORDER $(\mathrm{j}, \mathrm{k}, \mathrm{t}))$ \\
\hline $\mathrm{j}=1 . . \mathrm{M}$ for each customer $(\mathrm{j})$ in the set of customers & $@$ FOR(CUSTOMERS $(\mathrm{j}))$ \\
\hline$\bullet$ & $*$ \\
\hline$=$ & $=$ \\
\hline $\mathrm{X} \in$ integer & $@ \operatorname{gin}(\mathrm{X})$ \\
\hline $\mathrm{X} \in\{0,1\}$ & $@ \mathrm{bin}(\mathrm{X})$ \\
\hline Load input parameters $\mathrm{p}$ from the file dane.ldt & $\mathrm{p}=@$ ,file(dane.ldt $)$ \\
\hline
\end{tabular}

For real examples with sizes exceeding several decision variables, the construction and implementation of the model is only possible using the modeling language (see Listing 1).

The basic elements of LINGO mathematical modeling language syntax are presented in Table 2. The model can be saved as a text file using any text editor and with a standard extension *. lng and *. ldt data file. The structure of the model is composed of sections. The main section is the MODEL section, which begins with the word MODEL: and ends with the word END. Other sections may be integrated in this section. The most important sections, highlighted by the relevant keywords are: section SETS (SET: ENDSETS) and DATE (DATE: enddate). In the SETS section you can define types of simple or complex objects and their mutual relationships. In the implemented model, types such as products, factories, etc. correspond to simple objects; complex objects cover production, distribution, etc. In this section, the parameters and variables of the model are assigned to particular types. DATA section allows initiating or assigning values to individual parameters of the model. There are two methods to do it in the LINGO package: either place numerical data directly in the section or make references to the place where those data files are included. This method of model construction ensures the separation of data from the relevant model, which is very important because the change in data values or even their size does not require any changes in the objective function or constraints. Only the model implemented in the implicit form has such a feature.

Listing 1. Implementation of the mathematical model in LINGO package

\begin{tabular}{|c|c|c|}
\hline ! $\mathrm{k}$ & - product type & $0=5 ;$ \\
\hline ! j & - customers & $M=4 ;$ \\
\hline ! i & - factory & $\mathrm{N}=2 ;$ \\
\hline ! s & - distributor & $E=3 ;$ \\
\hline ! t & - period & $\mathrm{H}=10 ;$ \\
\hline ! d & - mode & $L=4 ;$ \\
\hline \multicolumn{3}{|c|}{ Model: } \\
\hline \multicolumn{3}{|c|}{ Sets: } \\
\hline & products & /1..efile(rozmiary.ldt)/:p; \\
\hline & factory & /1..afile(rozmiary.ldt)/; \\
\hline & customers & /1..efile(rozmiary.ldt)/; \\
\hline & distributors & /1..afile(rozmiary.ldt)/:f,v,vx, T; \\
\hline & mode & /1..dfile(rozmiary.ldt)/:pt, zt,od, dx; \\
\hline & order & (customers, products) : z, tc \\
\hline & production & (factory, products) : c, w, wx \\
\hline & location & (distributors, products) $: r, t p$ \\
\hline & supplies_mode_1 & (factory, distributors, mode) : a, r1, tf, Xb, Xa, ko_1; \\
\hline & supplies_mode_2 & (distributors, customers, mode) : $g, r 2, t m, Y b, \mathrm{Ya}_{1} \overline{\mathrm{k}} \mathrm{O} \_2$; \\
\hline & supp_mode__1 & (factory, distributors, products, mode) : $\mathrm{x}, \mathrm{k} 1$ \\
\hline & supp_mode_2 & (distributors, customers, products, mode): $\mathrm{Y}, \mathrm{k} 2$; \\
\hline & supp_period_1 & (factory, distributors, products) ; \\
\hline & supp_period_2 & (distributors, customers, products) ; \\
\hline \multicolumn{3}{|c|}{ EndSets } \\
\hline \multicolumn{3}{|c|}{ Data: } \\
\hline $\mathrm{p}$ & =afile (dane.ldt); & \\
\hline f & $=$ afile (dane.ldt); & \\
\hline $\mathrm{v}$ & $=$ afile (dane.ldt); & \\
\hline pt & $=@ f i l e(d a n e . l d t)$; & \\
\hline zt & =afile (dane.ldt); & \\
\hline z & $=$ afile (dane.ldt); & \\
\hline
\end{tabular}


Listing 1. Implementation of the mathematical model in LINGO package (continued)

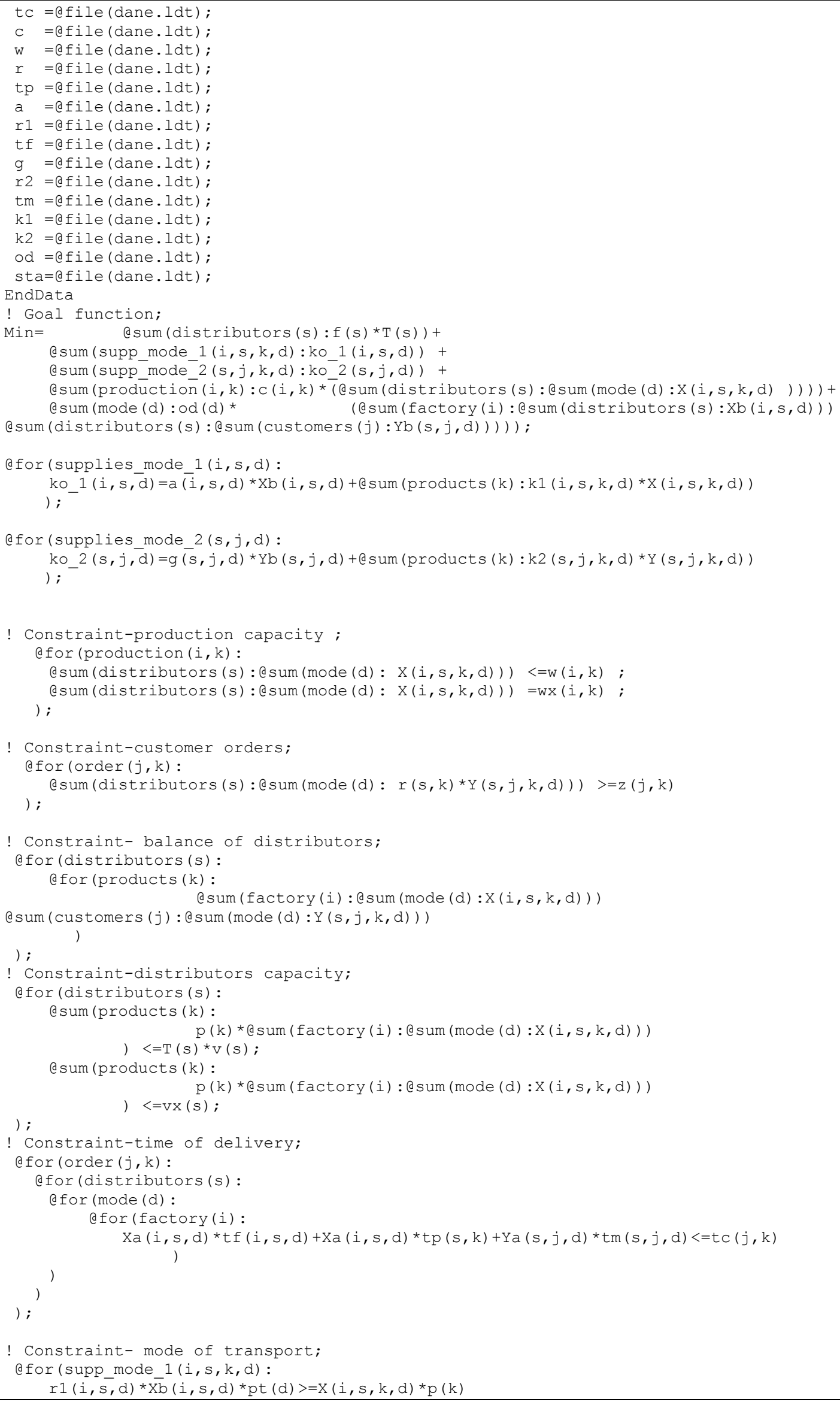


Listing 1. Implementation of the mathematical model in LINGO package (continued)

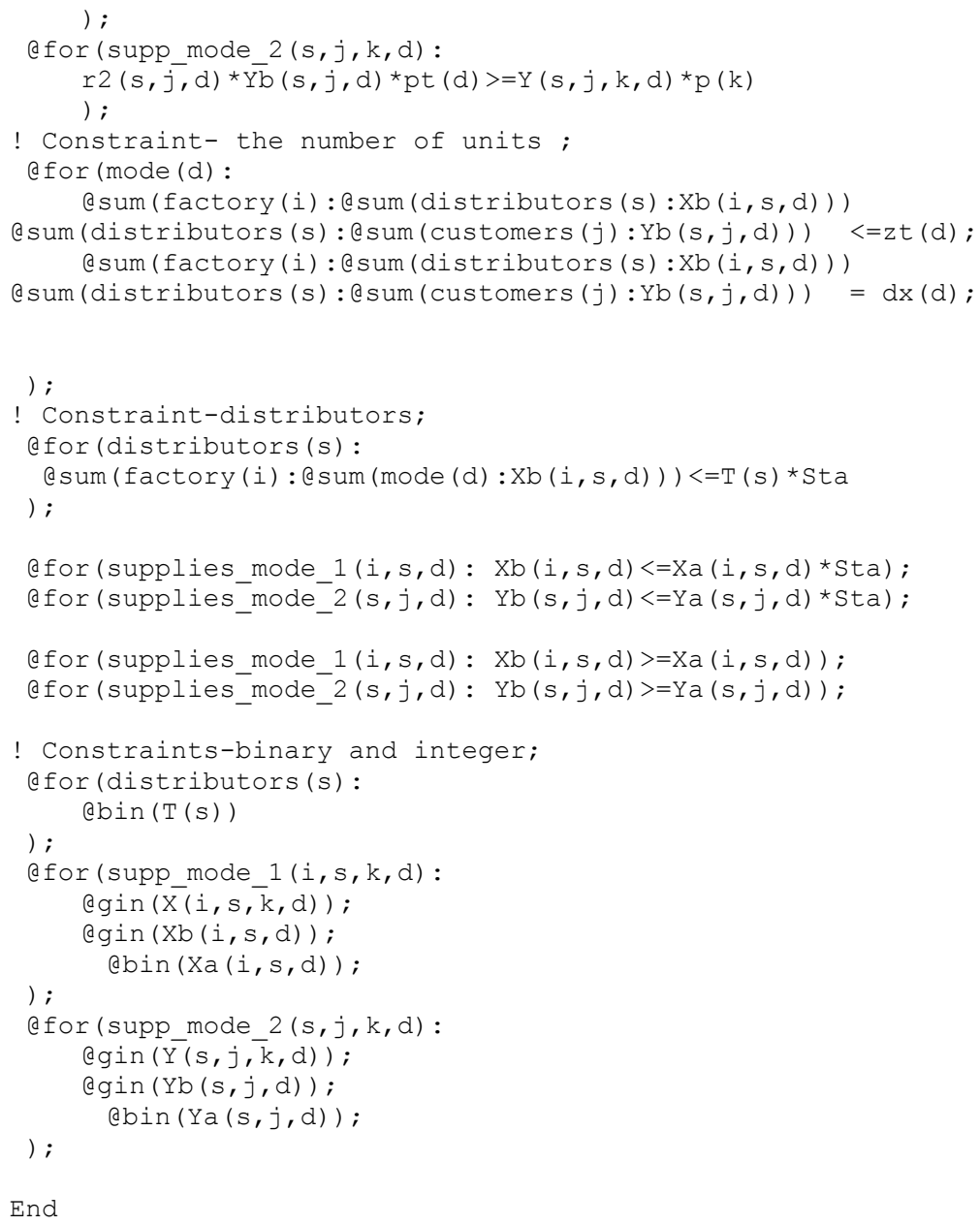

\section{Computational examples}

The mathematical model (1)..(24) was implemented in the LINGO environment. All acceptable modes of transport among the participants in the supply chain for the computational examples are in Fig. 5. For clarity, all possible modes of transport are presented in separate diagrams.

Optimization was performed for examples: P1 to P7. All examples relate to the supply chain in which there are two manufacturers $(\mathrm{I}=1 . .2)$, three distributors $(\mathrm{s}=$ $1 . .3$ ), four recipients $(j=1 . .4)$, five types of products $(\mathrm{k}=1 . .5)$, three modes of transport $(\mathrm{d}=1 . .3)$.

The examples differ in capacity available to the distributors $\left(\mathrm{V}_{\mathrm{s}}\right)$ and the environmental cost of using mode of transport $d\left(\mathrm{Od}_{\mathrm{d}}\right)$. The numerical data for all the model parameters from Table 1 are presented in Table 3.

Decision variables of the model are directly or indirectly related to the mode of delivery (customer orders) for operational decisions. These decisions refer to proper volume supply of particular products and the number of runs in a specific mode of transport.

Full list of non-zero decision variables which optimize the objective function $(\mathrm{Fc}=37820)$, for example, P1 is shown in Table 4. Fig. 6 illustrates that the modes of transport have been selected for various routes for the optimal solution. On the basis of these results it is possible to draw conclusions about the structure of the supply chain and transportation. Decisions resulting from the conclusions are long-term decisions concerning, for instance, distribution capacity, production capacity etc. For further studies and especially longterm decision support, the optimization model was extended in the implementation stage. To better support this type of decision, the authors have introduced additional decision variables which do not affect the value of the objective function nor make the mathematical model more complicated. The variables were introduced only at the implementing level. LINGO system ensures such possibilities. Three new decision variables 
were introduced: $\mathrm{Wx}_{\mathrm{ik}}$ (level of capacity utilization for the product $\mathrm{k}$ the factory $\mathrm{i}$ ), $\mathrm{Vx}_{\mathrm{s}}$ (capacity/volume utilization for distributor $s$ ) and $\mathrm{Dx}_{\mathrm{d}}$ (total number of courses of transport mode d). Sample values of implementation decision variables $\mathrm{Vx}_{\mathrm{t}}, \mathrm{Wx}_{\mathrm{ikt}}, \mathrm{Dx}_{\mathrm{d}}$ for example P1 are presented in Table 4.
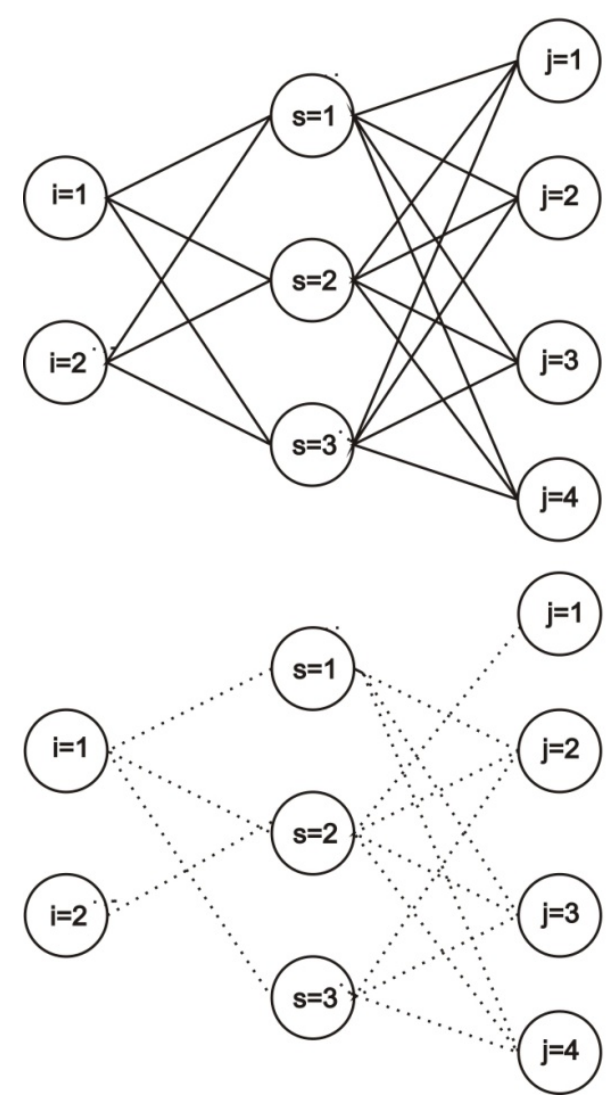

Figure 5. The all acceptable modes of transport among the participants in the supply chain for the computational examples

(source: own work)
Due to the size, detailed results of the optimization (non-zero values for all decision variables) are shown only for example P1. For examples from P2 to P7 only the result of optimization is shown, i.e. the value of the objective function and the corresponding multimodal network (see Fig. 7 to 12).

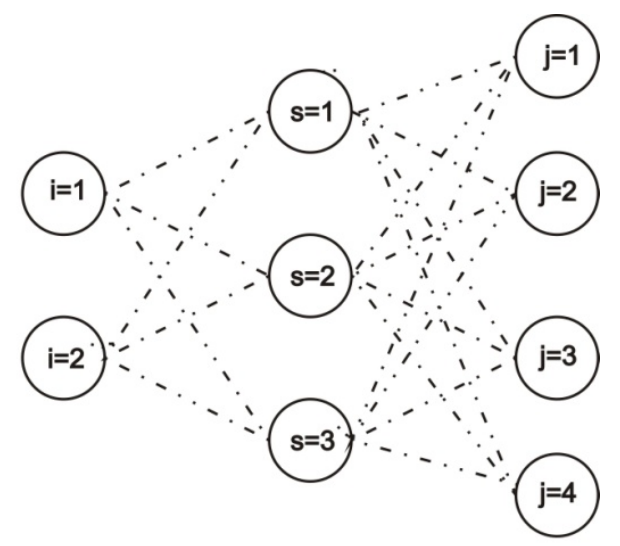

mode of transport $d$

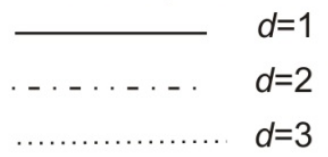

Table 3. The set of tables with numerical data for examples P1..P7 (source: own work)

\begin{tabular}{|c|c|c|c|c|c|}
\hline \multirow{2}{*}{$\mathbf{s}$} & \multirow{2}{*}{$\mathbf{F}_{\mathbf{s}}$} & $\mathbf{P 1 ,} \mathbf{P 5}, \mathbf{P 6}, \mathbf{P 7}$ & $\mathbf{P 2}$ & $\mathbf{P 3}$ & $\mathbf{P 4}$ \\
\cline { 3 - 6 } & 1200 & $\mathbf{V}_{\mathbf{s}}$ & $\mathbf{V}_{\mathbf{s}}$ & $\mathbf{V}_{\mathbf{s}}$ & $\mathbf{V}_{\mathbf{s}}$ \\
\hline 1 & 1500 & 1300 & 1600 & 2200 \\
\hline 2 & 1500 & 1500 & 1300 & 1600 & 2200 \\
\hline 3 & 1000 & 1500 & 1300 & 1600 & 2200 \\
\hline
\end{tabular}

\begin{tabular}{|c|c|c|c|c|c|c|}
\hline \multirow{2}{*}{$\mathbf{d}$} & \multirow{2}{*}{$\mathbf{P t}_{\mathbf{d}}$} & \multirow{2}{*}{$\mathbf{Z t}_{\mathbf{d}}$} & $\mathbf{P 1}, \mathbf{P 2}, \mathbf{P 3}, \mathbf{P 4}$ & $\mathbf{P 5}$ & $\mathbf{P 6}$ & $\mathbf{P 7}$ \\
\cline { 4 - 7 } & & 10 & $\mathbf{C t}_{\mathbf{d}}$ & $\mathbf{C t}_{\mathbf{d}}$ & $\mathbf{C t}_{\mathbf{d}}$ & $\mathbf{C t}_{\mathbf{d}}$ \\
\hline 1 & 60 & 10 & 10 & 10 & 10 \\
\hline 2 & 180 & 10 & 60 & 30 & 60 & 120 \\
\hline 3 & 600 & 10 & 240 & 100 & 200 & 400 \\
\hline
\end{tabular}




\begin{tabular}{|c|c|c|c|c|c|c|c|c|c|c|c|c|c|c|c|}
\hline $\mathbf{j}$ & $\mathbf{k}$ & $\mathbf{Z}_{\mathbf{j k}}$ & $\mathbf{T c}_{\mathbf{j k}}$ & $\mathbf{j}$ & $\mathbf{k}$ & $\mathbf{Z}_{\mathbf{j k}}$ & $\mathbf{T c}_{\mathbf{j k}}$ & $\mathbf{j}$ & $\mathbf{k}$ & $\mathbf{Z}_{\mathbf{j k}}$ & $\mathbf{T c}_{\mathbf{j k}}$ & $\mathbf{j}$ & $\mathbf{k}$ & $\mathbf{Z}_{\mathbf{j k}}$ & $\mathbf{T c}_{\mathbf{j k}}$ \\
\hline 1 & 1 & 10 & 10 & 2 & 1 & 10 & 10 & 3 & 1 & 10 & 10 & 4 & 1 & 10 & 10 \\
\hline 1 & 2 & 10 & 10 & 2 & 2 & 0 & 10 & 3 & 2 & 20 & 10 & 4 & 2 & 0 & 10 \\
\hline 1 & 3 & 5 & 10 & 2 & 3 & 10 & 10 & 3 & 3 & 0 & 10 & 4 & 3 & 10 & 10 \\
\hline 1 & 4 & 10 & 10 & 2 & 4 & 10 & 10 & 3 & 4 & 20 & 10 & 4 & 4 & 0 & 10 \\
\hline 1 & 5 & 5 & 20 & 2 & 5 & 5 & 20 & 3 & 5 & 0 & 20 & 4 & 5 & 15 & 20 \\
\hline
\end{tabular}

\begin{tabular}{|c|c|c|c|c|c|c|c|}
\hline $\mathbf{i}$ & $\mathbf{k}$ & $\mathbf{C}_{\text {ik }}$ & $\mathbf{W}_{\text {ik }}$ & $\mathbf{i}$ & $\mathbf{k}$ & $\mathbf{C}_{\text {ik }}$ & $\mathbf{W}_{\text {ik }}$ \\
\hline 1 & 1 & 100 & 100 & 2 & 1 & 150 & 100 \\
\hline 1 & 2 & 200 & 100 & 2 & 2 & 210 & 100 \\
\hline 1 & 3 & 200 & 100 & 2 & 3 & 150 & 100 \\
\hline 1 & 4 & 300 & 100 & 2 & 4 & 250 & 100 \\
\hline 1 & 5 & 300 & 100 & 2 & 5 & 350 & 100 \\
\hline
\end{tabular}

\begin{tabular}{|l|l|}
\hline $\mathbf{j}$ & $\mathbf{P}_{\mathbf{j}}$ \\
\hline 1 & 10 \\
\hline 2 & 15 \\
\hline 3 & 15 \\
\hline 4 & 10 \\
\hline 5 & 20 \\
\hline
\end{tabular}

\begin{tabular}{|c|c|c|c|c|c|c|c|c|c|c|c|}
\hline $\mathbf{s}$ & $\mathbf{k}$ & $\mathbf{R}_{\text {sk }}$ & $\mathbf{T} \mathbf{p}_{\text {sk }}$ & $\mathbf{s}$ & $\mathbf{k}$ & $\mathbf{R}_{\text {sk }}$ & $\mathbf{T} \mathbf{p}_{\text {sk }}$ & $\mathbf{s}$ & $\mathbf{k}$ & $\mathbf{R}_{\text {sk }}$ & $\mathbf{T p}_{\text {sk }}$ \\
\hline 1 & 1 & 1 & 2 & 2 & 1 & 1 & 1 & 3 & 1 & 0 & 0 \\
\hline 1 & 2 & 1 & 2 & 2 & 2 & 1 & 1 & 3 & 2 & 1 & 3 \\
\hline 1 & 3 & 1 & 2 & 2 & 3 & 1 & 1 & 3 & 3 & 1 & 3 \\
\hline 1 & 4 & 1 & 2 & 2 & 4 & 1 & 1 & 3 & 4 & 1 & 3 \\
\hline 1 & 5 & 1 & 2 & 2 & 5 & 1 & 1 & 3 & 5 & 1 & 3 \\
\hline
\end{tabular}

\begin{tabular}{|c|c|c|c|c|c|c|c|c|c|c|c|}
\hline $\mathbf{i}$ & $\mathbf{s}$ & $\mathbf{d}$ & $\mathbf{A}_{\text {isd }}$ & $\mathbf{R 1}_{\text {isd }}$ & $\mathbf{T f}_{\text {isd }}$ & $\mathbf{i}$ & $\mathbf{s}$ & $\mathbf{d}$ & $\mathbf{A}_{\text {isd }}$ & $\mathbf{R}_{\text {isd }}$ & $\mathbf{T f}_{\text {isd }}$ \\
\hline 1 & 1 & 1 & 10 & 1 & 2 & 2 & 1 & 1 & 5 & 1 & 4 \\
\hline 1 & 1 & 2 & 20 & 1 & 3 & 2 & 1 & 2 & 10 & 1 & 6 \\
\hline 1 & 1 & 3 & 40 & 1 & 4 & 2 & 1 & 3 & 20 & 0 & 7 \\
\hline 1 & 2 & 1 & 12 & 1 & 1 & 2 & 2 & 1 & 10 & 1 & 4 \\
\hline 1 & 2 & 2 & 24 & 1 & 2 & 2 & 2 & 2 & 20 & 1 & 6 \\
\hline 1 & 2 & 3 & 42 & 1 & 3 & 2 & 2 & 3 & 40 & 1 & 7 \\
\hline 1 & 3 & 1 & 5 & 1 & 1 & 2 & 3 & 1 & 15 & 1 & 4 \\
\hline 1 & 3 & 2 & 10 & 1 & 2 & 2 & 3 & 2 & 25 & 1 & 6 \\
\hline 1 & 3 & 3 & 25 & 1 & 3 & 2 & 3 & 3 & 35 & 0 & 7 \\
\hline
\end{tabular}

\begin{tabular}{|c|c|c|c|c|c|c|c|c|c|c|c|}
\hline $\mathbf{s}$ & $\mathbf{j}$ & $\mathbf{d}$ & $\mathbf{G}_{\text {isd }}$ & $\mathbf{R}_{\text {isd }}$ & $\mathbf{T m}_{\text {isd }}$ & $\mathbf{s}$ & $\mathbf{j}$ & $\mathbf{d}$ & $\mathbf{G}_{\text {isd }}$ & $\mathbf{R}_{\text {isd }}$ & $\mathbf{T}_{\text {isd }}$ \\
\hline 1 & 1 & 1 & 2 & 1 & 1 & 2 & 1 & 1 & 4 & 1 & 1 \\
\hline 1 & 1 & 2 & 4 & 1 & 1 & 2 & 1 & 2 & 8 & 1 & 1 \\
\hline 1 & 1 & 3 & 10 & 0 & 2 & 2 & 1 & 3 & 16 & 1 & 2 \\
\hline 1 & 2 & 1 & 2 & 1 & 1 & 2 & 2 & 1 & 3 & 1 & 1 \\
\hline 1 & 2 & 2 & 5 & 1 & 1 & 2 & 2 & 2 & 6 & 1 & 1 \\
\hline 1 & 2 & 3 & 12 & 1 & 2 & 2 & 2 & 3 & 15 & 1 & 2 \\
\hline 1 & 3 & 1 & 14 & 1 & 1 & 2 & 3 & 1 & 5 & 1 & 1 \\
\hline 1 & 3 & 2 & 12 & 1 & 1 & 2 & 3 & 2 & 10 & 1 & 1 \\
\hline 1 & 3 & 3 & 20 & 1 & 2 & 2 & 3 & 3 & 15 & 1 & 2 \\
\hline 1 & 4 & 1 & 15 & 1 & 1 & 2 & 4 & 1 & 2 & 1 & 1 \\
\hline 1 & 4 & 2 & 13 & 1 & 1 & 2 & 4 & 2 & 4 & 1 & 1 \\
\hline 1 & 4 & 3 & 30 & 1 & 2 & 2 & 4 & 3 & 10 & 1 & 2 \\
\hline 3 & 1 & 1 & 2 & 1 & 1 & 3 & 3 & 1 & 6 & 1 & 1 \\
\hline 3 & 1 & 2 & 4 & 1 & 1 & 3 & 3 & 2 & 10 & 1 & 1 \\
\hline 3 & 1 & 3 & 11 & 0 & 2 & 3 & 3 & 3 & 20 & 1 & 2 \\
\hline 3 & 2 & 1 & 3 & 1 & 1 & 3 & 4 & 1 & 4 & 1 & 1 \\
\hline 3 & 2 & 2 & 6 & 1 & 1 & 3 & 4 & 2 & 8 & 1 & 1 \\
\hline 3 & 2 & 3 & 14 & 1 & 2 & 3 & 4 & 3 & 20 & 1 & 2 \\
\hline
\end{tabular}




\begin{tabular}{|c|c|c|c|c|c|c|c|c|c|c|c|c|c|c|}
\hline $\mathbf{i}$ & $\mathbf{s}$ & $\mathbf{k}$ & $\mathbf{d}$ & $\mathbf{K} \mathbf{1}_{\text {iskd }}$ & $\mathbf{i}$ & $\mathbf{s}$ & $\mathbf{k}$ & $\mathbf{d}$ & $\mathbf{K} \mathbf{1}_{\text {iskd }}$ & $\mathbf{i}$ & $\mathbf{s}$ & $\mathbf{k}$ & $\mathbf{d}$ & $\mathbf{K} \mathbf{1}_{\text {iskd }}$ \\
\hline 1 & 1 & 1 & 1 & 3 & 1 & 2 & 1 & 1 & 4 & 1 & 3 & 1 & 1 & 3 \\
\hline 1 & 1 & 1 & 2 & 2 & 1 & 2 & 1 & 2 & 2 & 1 & 3 & 1 & 2 & 2 \\
\hline 1 & 1 & 1 & 3 & 1 & 1 & 2 & 1 & 3 & 1 & 1 & 3 & 1 & 3 & 1 \\
\hline 1 & 1 & 2 & 1 & 3 & 1 & 2 & 2 & 1 & 4 & 1 & 3 & 2 & 1 & 3 \\
\hline 1 & 1 & 2 & 2 & 2 & 1 & 2 & 2 & 2 & 2 & 1 & 3 & 2 & 2 & 2 \\
\hline 1 & 1 & 2 & 3 & 1 & 1 & 2 & 2 & 3 & 1 & 1 & 3 & 2 & 3 & 1 \\
\hline 1 & 1 & 3 & 1 & 3 & 1 & 2 & 3 & 1 & 4 & 1 & 3 & 3 & 1 & 3 \\
\hline 1 & 1 & 3 & 2 & 2 & 1 & 2 & 3 & 2 & 2 & 1 & 3 & 3 & 2 & 2 \\
\hline 1 & 1 & 3 & 3 & 1 & 1 & 2 & 3 & 3 & 1 & 1 & 3 & 3 & 3 & 1 \\
\hline 1 & 1 & 4 & 1 & 3 & 1 & 2 & 4 & 1 & 4 & 1 & 3 & 4 & 1 & 3 \\
\hline 1 & 1 & 4 & 2 & 2 & 1 & 2 & 4 & 2 & 2 & 1 & 3 & 4 & 2 & 2 \\
\hline 1 & 1 & 4 & 3 & 1 & 1 & 2 & 4 & 3 & 1 & 1 & 3 & 4 & 3 & 1 \\
\hline 1 & 1 & 5 & 1 & 3 & 1 & 2 & 5 & 1 & 4 & 1 & 3 & 5 & 1 & 3 \\
\hline 1 & 1 & 5 & 2 & 2 & 1 & 2 & 5 & 2 & 2 & 1 & 3 & 5 & 2 & 2 \\
\hline 1 & 1 & 5 & 3 & 1 & 1 & 2 & 5 & 3 & 1 & 1 & 3 & 5 & 3 & 1 \\
\hline 2 & 1 & 1 & 1 & 4 & 1 & 2 & 1 & 1 & 3 & 1 & 3 & 1 & 1 & 4 \\
\hline 2 & 1 & 1 & 2 & 2 & 2 & 2 & 1 & 2 & 2 & 2 & 3 & 1 & 2 & 2 \\
\hline 2 & 1 & 1 & 3 & 1 & 2 & 2 & 1 & 3 & 1 & 2 & 3 & 1 & 3 & 1 \\
\hline 2 & 1 & 2 & 1 & 4 & 2 & 2 & 2 & 1 & 3 & 2 & 3 & 2 & 1 & 4 \\
\hline 2 & 1 & 2 & 2 & 2 & 2 & 2 & 2 & 2 & 2 & 2 & 3 & 2 & 2 & 2 \\
\hline 2 & 1 & 2 & 3 & 1 & 2 & 2 & 2 & 3 & 1 & 2 & 3 & 2 & 3 & 1 \\
\hline 2 & 1 & 3 & 1 & 4 & 2 & 2 & 3 & 1 & 3 & 2 & 3 & 3 & 1 & 4 \\
\hline 2 & 1 & 3 & 2 & 2 & 2 & 2 & 3 & 2 & 2 & 2 & 3 & 3 & 2 & 2 \\
\hline 2 & 1 & 3 & 3 & 1 & 2 & 2 & 3 & 3 & 1 & 2 & 3 & 3 & 3 & 1 \\
\hline 2 & 1 & 4 & 1 & 4 & 2 & 2 & 4 & 1 & 3 & 2 & 3 & 4 & 1 & 4 \\
\hline 2 & 1 & 4 & 2 & 2 & 2 & 2 & 4 & 2 & 2 & 2 & 3 & 4 & 2 & 2 \\
\hline 2 & 1 & 4 & 3 & 1 & 2 & 2 & 4 & 3 & 1 & 2 & 3 & 4 & 3 & 1 \\
\hline 2 & 1 & 5 & 1 & 4 & 2 & 2 & 5 & 1 & 3 & 2 & 3 & 5 & 1 & 4 \\
\hline 2 & 1 & 5 & 2 & 2 & 2 & 2 & 5 & 2 & 2 & 2 & 3 & 5 & 2 & 2 \\
\hline 2 & 1 & 5 & 3 & 1 & 2 & 2 & 5 & 3 & 1 & 2 & 3 & 5 & 3 & 1 \\
\hline
\end{tabular}

\begin{tabular}{|c|c|c|c|c|c|c|c|c|c|c|c|c|c|c|}
\hline $\mathbf{s}$ & $\mathbf{j}$ & $\mathbf{k}$ & $\mathbf{d}$ & $\mathbf{K} \mathbf{2}_{\text {iskd }}$ & $\mathbf{s}$ & $\mathbf{j}$ & $\mathbf{k}$ & $\mathbf{d}$ & $\mathbf{K} \mathbf{2}_{\text {iskd }}$ & $\mathbf{s}$ & $\mathbf{j}$ & $\mathbf{k}$ & $\mathbf{d}$ & $\mathbf{K} \mathbf{i}_{\text {iskd }}$ \\
\hline 1 & 1 & 1 & 1 & 3 & 1 & 2 & 1 & 1 & 3 & 1 & 3 & 1 & 1 & 3 \\
\hline 1 & 1 & 1 & 2 & 2 & 1 & 2 & 1 & 2 & 2 & 1 & 3 & 1 & 2 & 2 \\
\hline 1 & 1 & 1 & 3 & 1 & 1 & 2 & 1 & 3 & 1 & 1 & 3 & 1 & 3 & 1 \\
\hline 1 & 1 & 2 & 1 & 3 & 1 & 2 & 2 & 1 & 3 & 1 & 3 & 2 & 1 & 3 \\
\hline 1 & 1 & 2 & 2 & 2 & 1 & 2 & 2 & 2 & 2 & 1 & 3 & 2 & 2 & 2 \\
\hline 1 & 1 & 2 & 3 & 1 & 1 & 2 & 2 & 3 & 1 & 1 & 3 & 2 & 3 & 1 \\
\hline 1 & 1 & 3 & 1 & 3 & 1 & 2 & 3 & 1 & 3 & 1 & 3 & 3 & 1 & 3 \\
\hline 1 & 1 & 3 & 2 & 2 & 1 & 2 & 3 & 2 & 2 & 1 & 3 & 3 & 2 & 2 \\
\hline 1 & 1 & 3 & 3 & 1 & 1 & 2 & 3 & 3 & 1 & 1 & 3 & 3 & 3 & 1 \\
\hline 1 & 1 & 4 & 1 & 3 & 1 & 2 & 4 & 1 & 3 & 1 & 3 & 4 & 1 & 3 \\
\hline 1 & 1 & 4 & 2 & 2 & 1 & 2 & 4 & 2 & 2 & 1 & 3 & 4 & 2 & 2 \\
\hline 1 & 1 & 4 & 3 & 1 & 1 & 2 & 4 & 3 & 1 & 1 & 3 & 4 & 3 & 1 \\
\hline 1 & 1 & 5 & 1 & 3 & 1 & 2 & 5 & 1 & 3 & 1 & 3 & 5 & 1 & 3 \\
\hline 1 & 1 & 5 & 2 & 2 & 1 & 2 & 5 & 2 & 2 & 1 & 3 & 5 & 2 & 2 \\
\hline 1 & 1 & 5 & 3 & 1 & 1 & 2 & 5 & 3 & 1 & 1 & 3 & 5 & 3 & 1 \\
\hline 1 & 4 & 1 & 1 & 3 & 2 & 1 & 1 & 1 & 3 & 2 & 2 & 1 & 1 & 3 \\
\hline 1 & 4 & 1 & 2 & 2 & 2 & 1 & 1 & 2 & 2 & 2 & 2 & 1 & 2 & 2 \\
\hline 1 & 4 & 1 & 3 & 1 & 2 & 1 & 1 & 3 & 1 & 2 & 2 & 1 & 3 & 1 \\
\hline 1 & 4 & 2 & 1 & 3 & 2 & 1 & 2 & 1 & 3 & 2 & 2 & 2 & 1 & 3 \\
\hline 1 & 4 & 2 & 2 & 2 & 2 & 1 & 2 & 2 & 2 & 2 & 2 & 2 & 2 & 2 \\
\hline 1 & 4 & 2 & 3 & 1 & 2 & 1 & 2 & 3 & 1 & 2 & 2 & 2 & 3 & 1 \\
\hline 1 & 4 & 3 & 1 & 3 & 2 & 1 & 3 & 1 & 3 & 2 & 2 & 3 & 1 & 3 \\
\hline 1 & 4 & 3 & 2 & 2 & 2 & 1 & 3 & 2 & 2 & 2 & 2 & 3 & 2 & 2 \\
\hline
\end{tabular}




\begin{tabular}{|c|c|c|c|c|c|c|c|c|c|c|c|c|c|c|}
\hline $\mathbf{s}$ & $\mathbf{j}$ & $\mathbf{k}$ & $\mathbf{d}$ & $\mathbf{K} \mathbf{i}_{\text {iskd }}$ & $\mathbf{s}$ & $\mathbf{j}$ & $\mathbf{k}$ & $\mathbf{d}$ & $\mathbf{K} \mathbf{2}_{\text {iskd }}$ & $\mathbf{s}$ & $\mathbf{j}$ & $\mathbf{k}$ & $\mathbf{d}$ & $\mathbf{K} \mathbf{~}_{\text {iskd }}$ \\
\hline 1 & 4 & 3 & 3 & 1 & 2 & 1 & 3 & 3 & 1 & 2 & 2 & 3 & 3 & 1 \\
\hline 1 & 4 & 4 & 1 & 3 & 2 & 1 & 4 & 1 & 3 & 2 & 2 & 4 & 1 & 3 \\
\hline 1 & 4 & 4 & 2 & 2 & 2 & 1 & 4 & 2 & 2 & 2 & 2 & 4 & 2 & 2 \\
\hline 1 & 4 & 4 & 3 & 1 & 2 & 1 & 4 & 3 & 1 & 2 & 2 & 4 & 3 & 1 \\
\hline 1 & 4 & 5 & 1 & 3 & 2 & 1 & 5 & 1 & 3 & 2 & 2 & 5 & 1 & 3 \\
\hline 1 & 4 & 5 & 2 & 2 & 2 & 1 & 5 & 2 & 2 & 2 & 2 & 5 & 2 & 2 \\
\hline 1 & 4 & 5 & 3 & 1 & 2 & 1 & 5 & 3 & 1 & 2 & 2 & 5 & 3 & 1 \\
\hline 2 & 3 & 1 & 1 & 3 & 2 & 4 & 1 & 1 & 3 & 3 & 1 & 1 & 1 & 3 \\
\hline 2 & 3 & 1 & 2 & 2 & 2 & 4 & 1 & 2 & 2 & 3 & 1 & 1 & 2 & 2 \\
\hline 2 & 3 & 1 & 3 & 1 & 2 & 4 & 1 & 3 & 1 & 3 & 1 & 1 & 3 & 1 \\
\hline 2 & 3 & 2 & 1 & 3 & 2 & 4 & 2 & 1 & 3 & 3 & 1 & 2 & 1 & 3 \\
\hline 2 & 3 & 2 & 2 & 2 & 2 & 4 & 2 & 2 & 2 & 3 & 1 & 2 & 2 & 2 \\
\hline 2 & 3 & 2 & 3 & 1 & 2 & 4 & 2 & 3 & 1 & 3 & 1 & 2 & 3 & 1 \\
\hline 2 & 3 & 3 & 1 & 3 & 2 & 4 & 3 & 1 & 3 & 3 & 1 & 3 & 1 & 3 \\
\hline 2 & 3 & 3 & 2 & 2 & 2 & 4 & 3 & 2 & 2 & 3 & 1 & 3 & 2 & 2 \\
\hline 2 & 3 & 3 & 3 & 1 & 2 & 4 & 3 & 3 & 1 & 3 & 1 & 3 & 3 & 1 \\
\hline 2 & 3 & 4 & 1 & 3 & 2 & 4 & 4 & 1 & 3 & 3 & 1 & 4 & 1 & 3 \\
\hline 2 & 3 & 4 & 2 & 2 & 2 & 4 & 4 & 2 & 2 & 3 & 1 & 4 & 2 & 2 \\
\hline 2 & 3 & 4 & 3 & 1 & 2 & 4 & 4 & 3 & 1 & 3 & 1 & 4 & 3 & 1 \\
\hline 2 & 3 & 5 & 1 & 3 & 2 & 4 & 5 & 1 & 3 & 3 & 1 & 5 & 1 & 3 \\
\hline 2 & 3 & 5 & 2 & 2 & 2 & 4 & 5 & 2 & 2 & 3 & 1 & 5 & 2 & 2 \\
\hline 2 & 3 & 5 & 3 & 1 & 2 & 4 & 5 & 3 & 1 & 3 & 1 & 5 & 3 & 1 \\
\hline 3 & 2 & 1 & 1 & 3 & 3 & 3 & 1 & 1 & 3 & 3 & 4 & 1 & 1 & 3 \\
\hline 3 & 2 & 1 & 2 & 2 & 3 & 3 & 1 & 2 & 2 & 3 & 4 & 1 & 2 & 2 \\
\hline 3 & 2 & 1 & 3 & 1 & 3 & 3 & 1 & 3 & 1 & 3 & 4 & 1 & 3 & 1 \\
\hline 3 & 2 & 2 & 1 & 3 & 3 & 3 & 2 & 1 & 3 & 3 & 4 & 2 & 1 & 3 \\
\hline 3 & 2 & 2 & 2 & 2 & 3 & 3 & 2 & 2 & 2 & 3 & 4 & 2 & 2 & 2 \\
\hline 3 & 2 & 2 & 3 & 1 & 3 & 3 & 2 & 3 & 1 & 3 & 4 & 2 & 3 & 1 \\
\hline 3 & 2 & 3 & 1 & 3 & 3 & 3 & 3 & 1 & 3 & 3 & 4 & 3 & 1 & 3 \\
\hline 3 & 2 & 3 & 2 & 2 & 3 & 3 & 3 & 2 & 2 & 3 & 4 & 3 & 2 & 2 \\
\hline 3 & 2 & 3 & 3 & 1 & 3 & 3 & 3 & 3 & 1 & 3 & 4 & 3 & 3 & 1 \\
\hline 3 & 2 & 4 & 1 & 3 & 3 & 3 & 4 & 1 & 3 & 3 & 4 & 4 & 1 & 3 \\
\hline 3 & 2 & 4 & 2 & 2 & 3 & 3 & 4 & 2 & 2 & 3 & 4 & 4 & 2 & 2 \\
\hline 3 & 2 & 4 & 3 & 1 & 3 & 3 & 4 & 3 & 1 & 3 & 4 & 4 & 3 & 1 \\
\hline 3 & 2 & 5 & 1 & 3 & 3 & 3 & 5 & 1 & 3 & 3 & 4 & 5 & 1 & 3 \\
\hline 3 & 2 & 5 & 2 & 2 & 3 & 3 & 5 & 2 & 2 & 3 & 4 & 5 & 2 & 2 \\
\hline 3 & 2 & 5 & 3 & 1 & 3 & 3 & 5 & 3 & 1 & 3 & 4 & 5 & 3 & 1 \\
\hline
\end{tabular}

Table 4. The set of tables with results (decision variables: $\mathrm{X}_{\mathrm{iskd}}, \mathrm{Xb}_{\mathrm{isk}}, \mathrm{Y}_{\mathrm{sjkd}}, \mathrm{Yb}_{\mathrm{sjk}}, \mathrm{Wx}_{\mathrm{ik}}, \mathrm{Vx}_{\mathrm{s}}, \mathrm{Dx}_{\mathrm{d}}$ ) for example P1 $\left(\mathrm{Fc}^{\mathrm{opt}}=37820\right)$

(source: own work)

\begin{tabular}{|c|c|c|c|c|c|c|c|c|}
\hline $\mathbf{i}$ & $\mathbf{s}$ & $\mathbf{k}$ & d & $\mathbf{X}_{\text {iskd }}$ & $\mathbf{i}$ & $\mathbf{s}$ & d & $\mathbf{X b}_{\text {isk }}$ \\
\hline 1 & 1 & 1 & 3 & 40.00 & \multirow{3}{*}{1} & \multirow{3}{*}{1} & \multirow{3}{*}{3} & \multirow{3}{*}{1} \\
\hline 1 & 1 & 2 & 3 & 23.00 & & & & \\
\hline 1 & 1 & 5 & 3 & 16.00 & & & & \\
\hline 1 & 3 & 2 & 2 & 7.00 & \multirow{2}{*}{1} & \multirow{2}{*}{3} & \multirow{2}{*}{2} & \multirow{2}{*}{1} \\
\hline 1 & 3 & 5 & 2 & 9.00 & & & & \\
\hline 2 & 1 & 3 & 1 & 1.00 & \multirow[b]{2}{*}{2} & \multirow{2}{*}{1} & \multirow{2}{*}{1} & \multirow[b]{2}{*}{1} \\
\hline 2 & 1 & 4 & 1 & 6.00 & & & & \\
\hline 2 & 1 & 3 & 2 & 12.00 & \multirow{2}{*}{2} & \multirow{2}{*}{1} & \multirow{2}{*}{2} & \multirow{2}{*}{1} \\
\hline 2 & 1 & 4 & 2 & 18.00 & & & & \\
\hline 2 & 3 & 3 & 2 & 12.00 & \multirow{2}{*}{2} & \multirow{2}{*}{3} & \multirow{2}{*}{2} & \multirow{2}{*}{1} \\
\hline 2 & 3 & 4 & 2 & 16.00 & & & & \\
\hline
\end{tabular}




\begin{tabular}{|c|c|c|c|c|c|c|c|c|}
\hline $\mathbf{s}$ & $\mathbf{j}$ & $\mathbf{k}$ & d & $\mathbf{Y}_{\mathrm{sjkd}}$ & $\mathbf{s}$ & $\mathbf{j}$ & d & $Y b_{\text {sjk }}$ \\
\hline 1 & 1 & 1 & 2 & 10.00 & \multirow{3}{*}{1} & \multirow{3}{*}{1} & \multirow{3}{*}{2} & \multirow{3}{*}{1} \\
\hline 1 & 1 & 2 & 2 & 3.00 & & & & \\
\hline 1 & 1 & 5 & 2 & 2.00 & & & & \\
\hline 1 & 2 & 1 & 2 & 10.00 & \multirow{4}{*}{1} & \multirow{4}{*}{2} & \multirow{4}{*}{2} & \multirow{4}{*}{1} \\
\hline 1 & 2 & 3 & 2 & 10.00 & & & & \\
\hline 1 & 2 & 4 & 2 & 4.00 & & & & \\
\hline 1 & 2 & 5 & 2 & 5.00 & & & & \\
\hline 1 & 3 & 1 & 3 & 10.00 & \multirow{3}{*}{1} & \multirow{3}{*}{3} & \multirow{3}{*}{3} & \multirow{3}{*}{1} \\
\hline 1 & 3 & 2 & 3 & 20.00 & & & & \\
\hline 1 & 3 & 4 & 3 & 20.00 & & & & \\
\hline 1 & 4 & 1 & 2 & 10.00 & \multirow{3}{*}{1} & \multirow{3}{*}{4} & \multirow{3}{*}{2} & \multirow{3}{*}{1} \\
\hline 1 & 4 & 3 & 2 & 3.00 & & & & \\
\hline 1 & 4 & 5 & 2 & 9.00 & & & & \\
\hline 3 & 1 & 2 & 2 & 7.00 & \multirow{4}{*}{3} & \multirow{4}{*}{1} & \multirow{4}{*}{2} & \multirow{4}{*}{1} \\
\hline 3 & 1 & 3 & 2 & 5.00 & & & & \\
\hline 3 & 1 & 4 & 2 & 10.00 & & & & \\
\hline 3 & 1 & 5 & 2 & 3.00 & & & & \\
\hline 3 & 2 & 4 & 1 & 6.00 & 3 & 2 & 1 & 1 \\
\hline 3 & 4 & 3 & 2 & 7.00 & \multirow{2}{*}{3} & \multirow{2}{*}{4} & \multirow{2}{*}{2} & \multirow{2}{*}{1} \\
\hline 3 & 4 & 5 & 2 & 6.00 & & & & \\
\hline
\end{tabular}

\begin{tabular}{|c|c|}
\hline $\mathbf{s}$ & $\mathbf{V x}_{\mathbf{s}}$ \\
\hline 1 & 1500 \\
\hline 2 & 0 \\
\hline 3 & 625 \\
\hline
\end{tabular}

\begin{tabular}{|c|c|c|}
\hline $\mathbf{i}$ & $\mathbf{k}$ & $\mathbf{W x}_{\mathbf{i k}}$ \\
\hline 1 & 1 & 40 \\
\hline 1 & 2 & 30 \\
\hline 1 & 5 & 25 \\
\hline 2 & 3 & 25 \\
\hline 2 & 4 & 40 \\
\hline
\end{tabular}

\begin{tabular}{|c|c|}
\hline $\mathbf{d}$ & $\mathbf{D x}_{\mathbf{d}}$ \\
\hline 1 & 2 \\
\hline 2 & 8 \\
\hline 3 & 2 \\
\hline
\end{tabular}
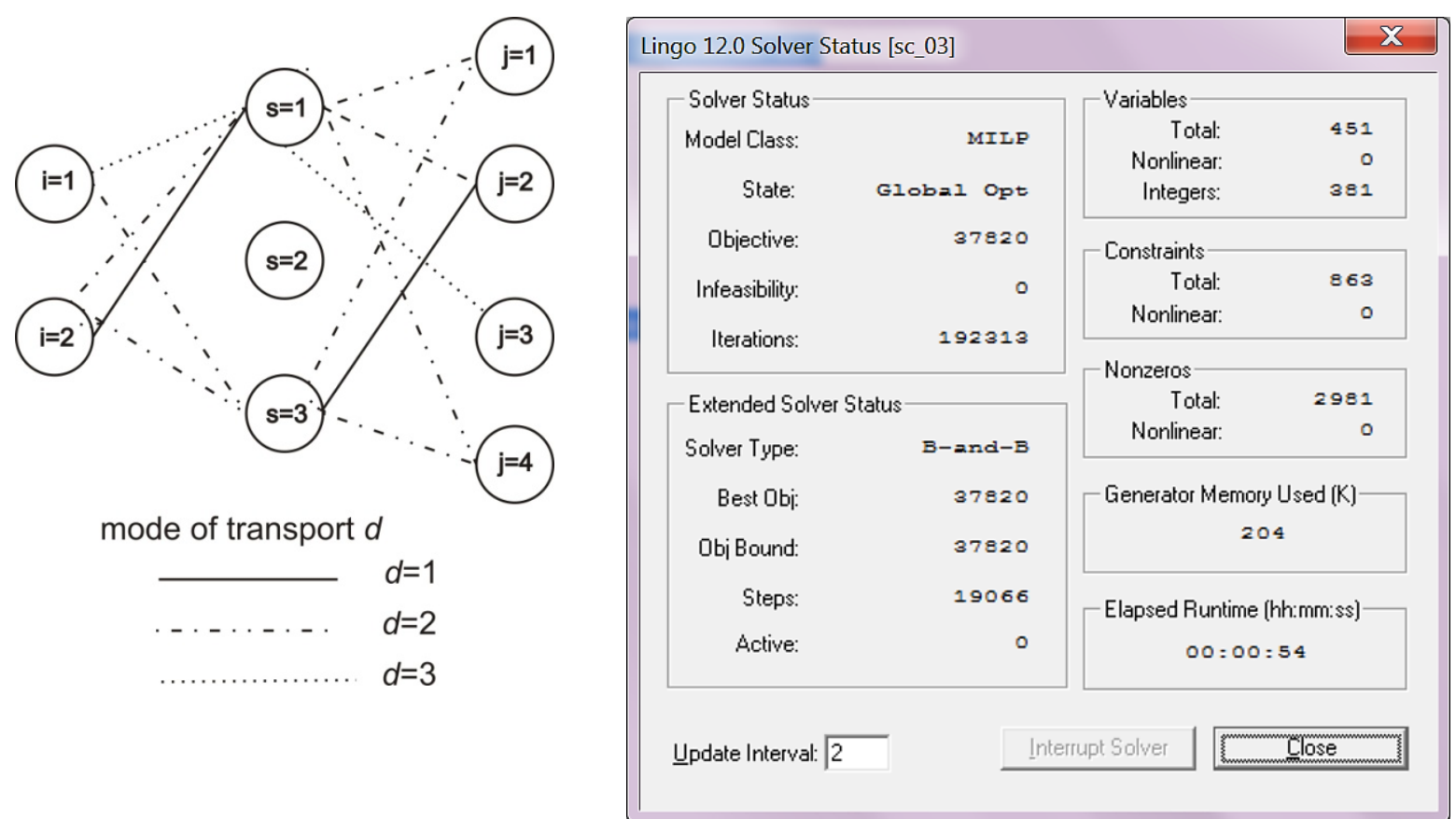

Figure 6. Left-hand side: a network of multi-modal optimal solution $\left(\mathrm{Fc}^{\mathrm{opt}}=37820\right)$ for P1.

Right-hand side: a screen shot of an optimal solution for P1. 


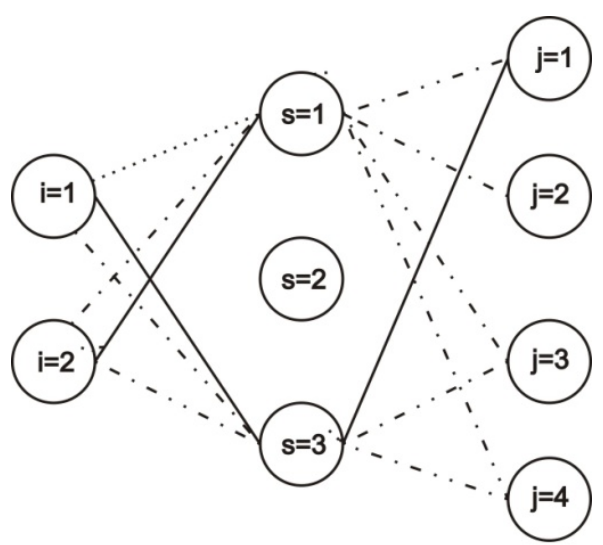

mode of transport $d$

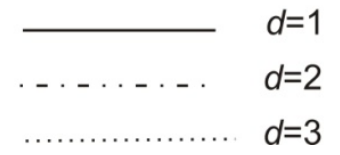

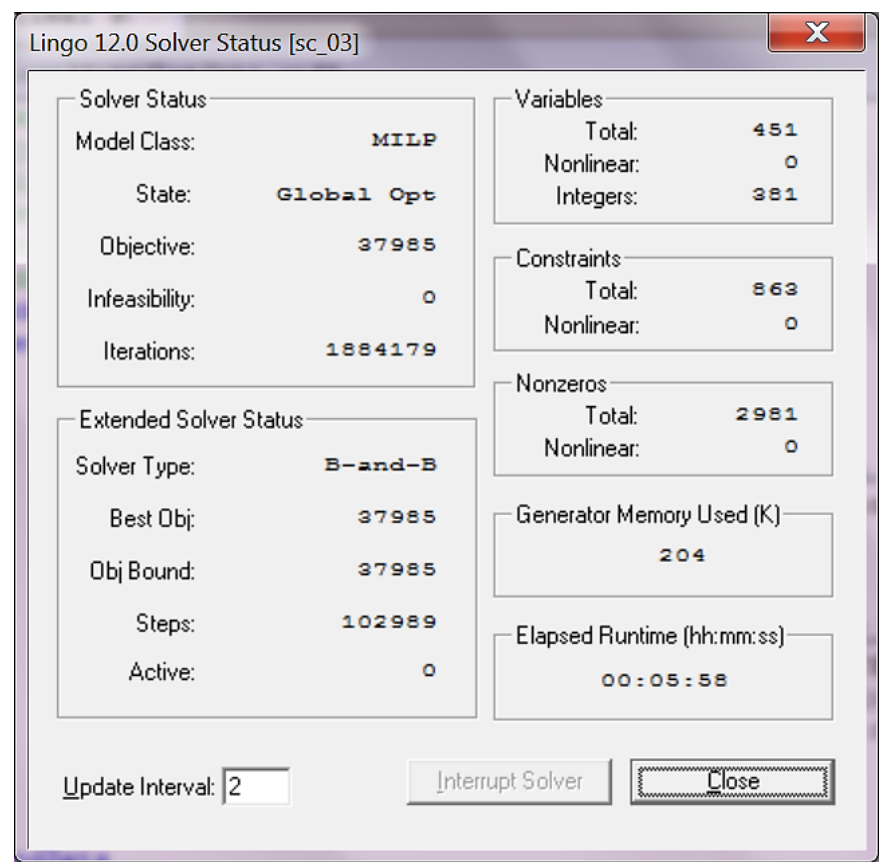

Figure 7. Left-hand side: a network of multi-modal optimal solution $\left(\mathrm{Fc}^{\mathrm{opt}}=379850\right)$ for $\mathrm{P} 2$.

Right-hand side: a screen shot of an optimal solution for P2

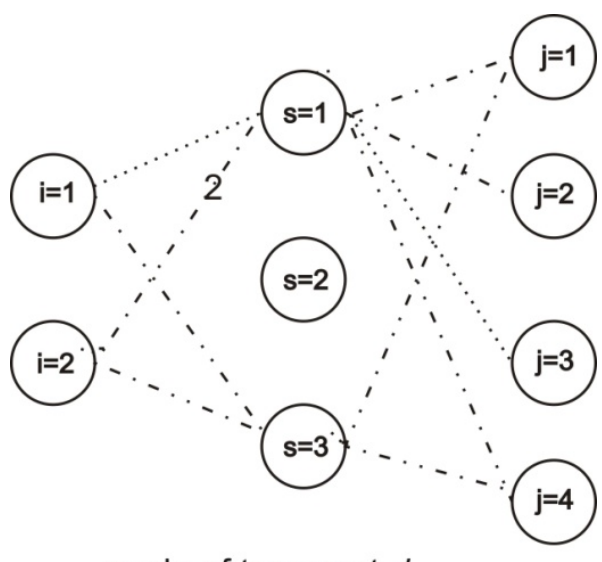

mode of transport $d$

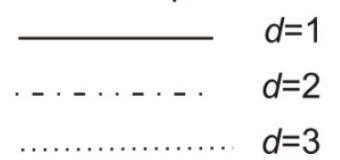

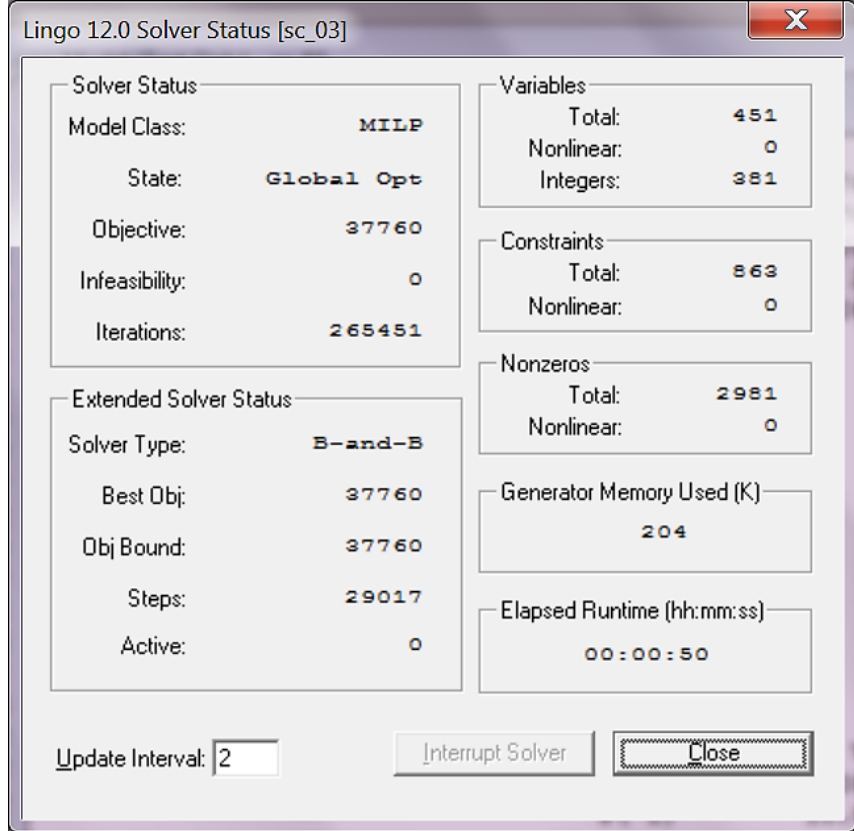

Figure 8. Left-hand side: a network of multi-modal optimal solution $\left(\mathrm{Fc}^{\mathrm{opt}}=37760\right)$ for P3.

Right-hand side: a screen shot of an optimal solution for P3 


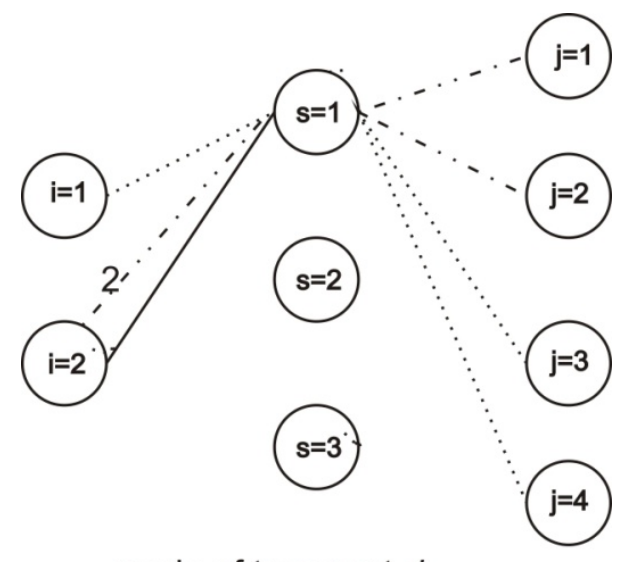

mode of transport $d$

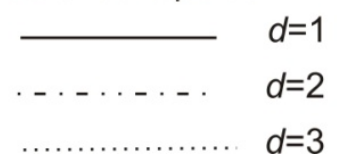

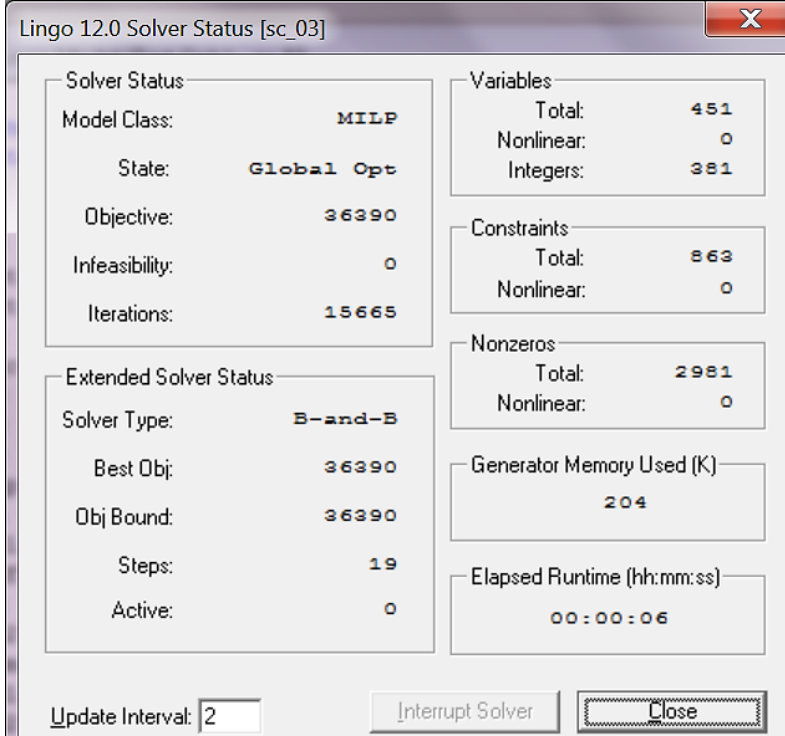

Update Interval: 2

Figure 9. Left-hand side: a network of multi-modal optimal solution $\left(\mathrm{Fc}^{\mathrm{opt}}=36390\right)$ for $\mathrm{P} 4$.

Right-hand side: a screen shot of an optimal solution for P4

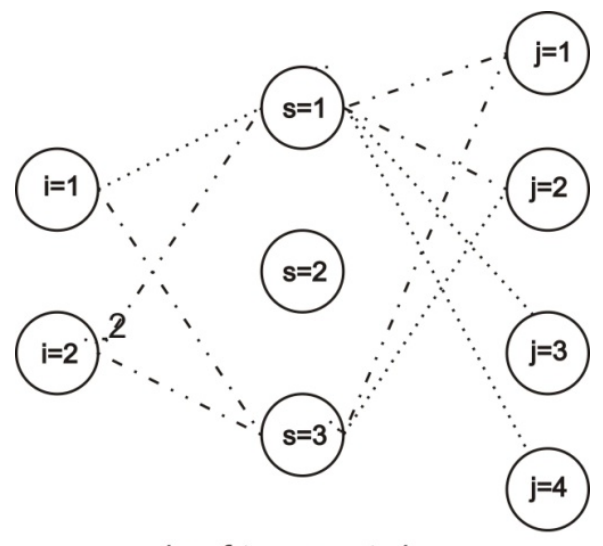

mode of transport $d$

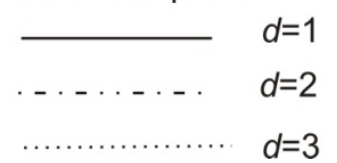

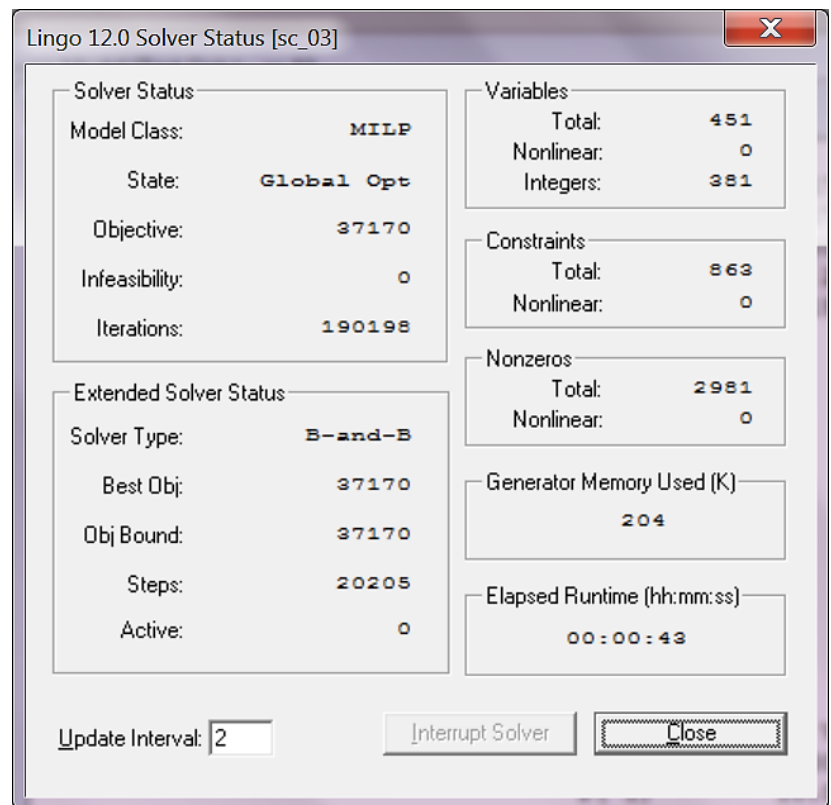

Figure 10. Left-hand side: a network of multi-modal optimal solution $\left(\mathrm{Fc}^{\mathrm{opt}}=37170\right)$ for P5.

Right-hand side: a screen shot of an optimal solution for P5 


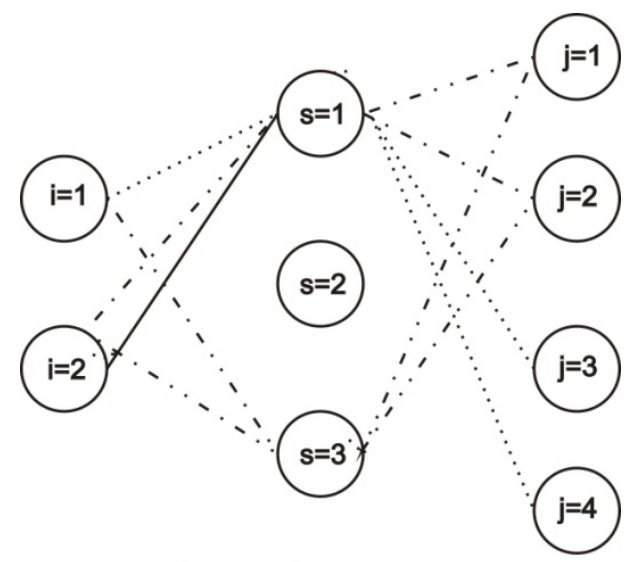

mode of transport $d$

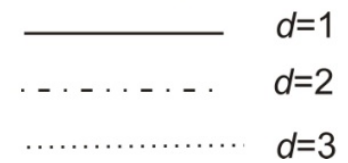

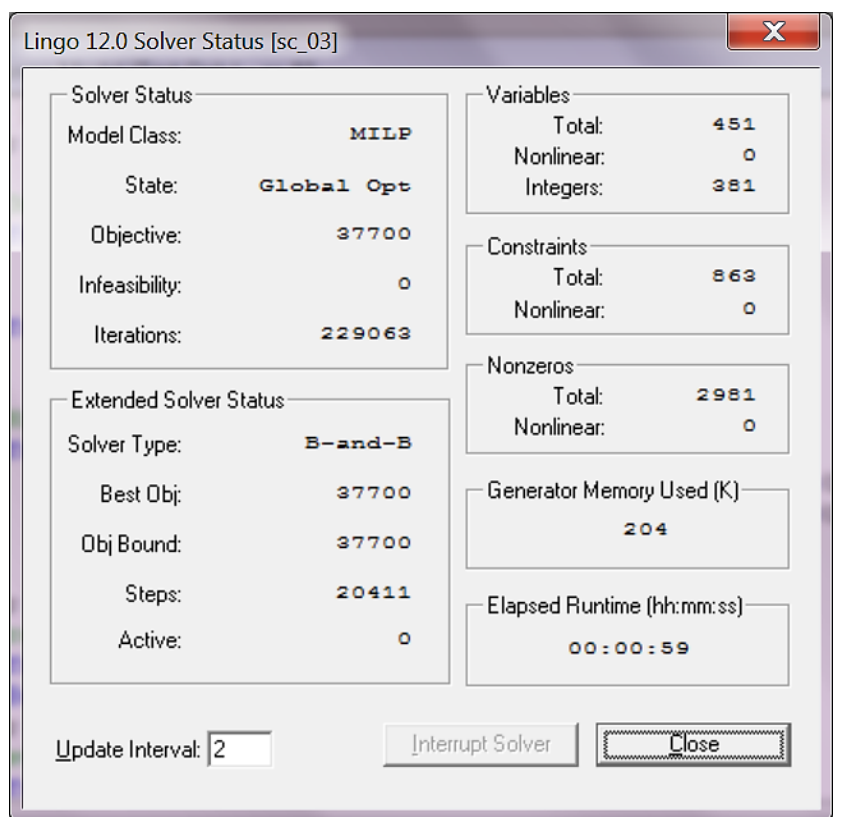

Figure 11. Left-hand side: a network of multi-modal optimal solution $\left(\mathrm{Fc}^{\mathrm{opt}}=37700\right)$ for P6.

Right-hand side: a screen shot of an optimal solution for P6

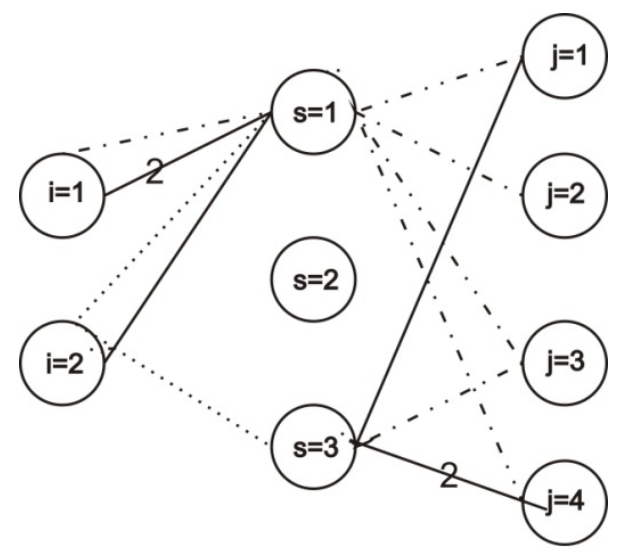

mode of transport $d$

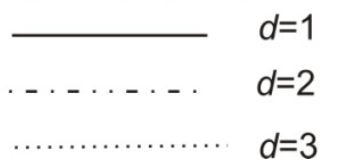

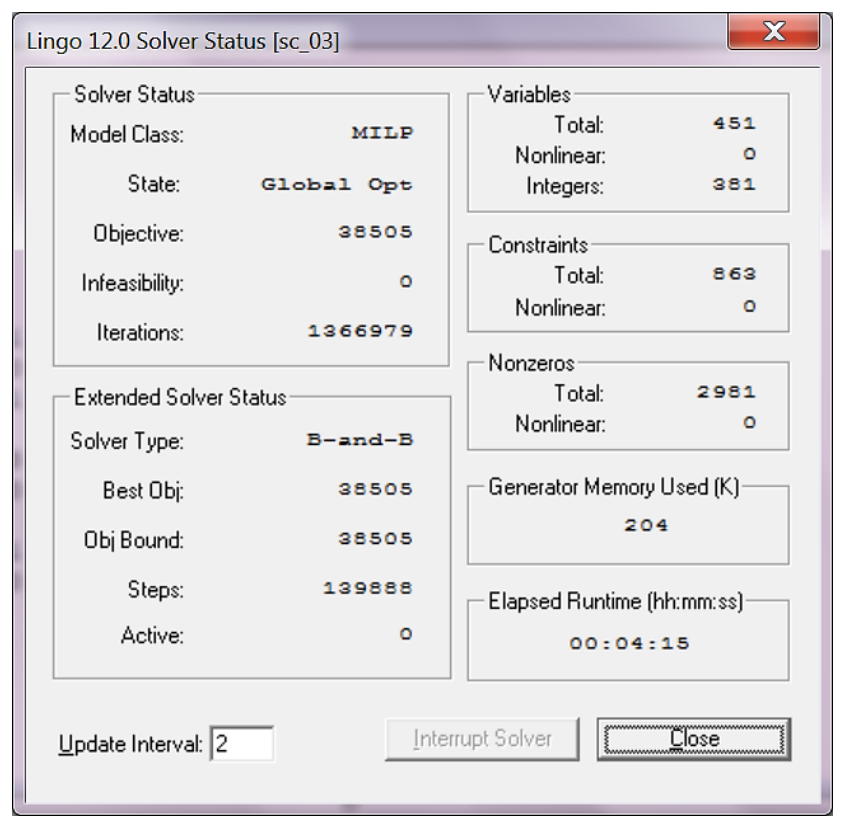

Figure12. Left-hand side: a network of multi-modal optimal solution $\left(\mathrm{Fc}^{\mathrm{opt}}=38505\right)$ for P7.

Right-hand side: a screen shot of an optimal solution for P7

To estimate the influence of parameters on the solution, additional experiments were carried out (much more than P1 .. P7). The effect of selected parameter $\left(\mathrm{V}_{\mathrm{s}}\right)$ on the solution is presented on chart (see Fig. 13). For these studies assumed that the values of other pa- rameters are the same as for example P1. As shown in the diagram (see Fig. 13) the value of the parameter $\mathrm{V}$ affects almost linearly the value of the objective function. 


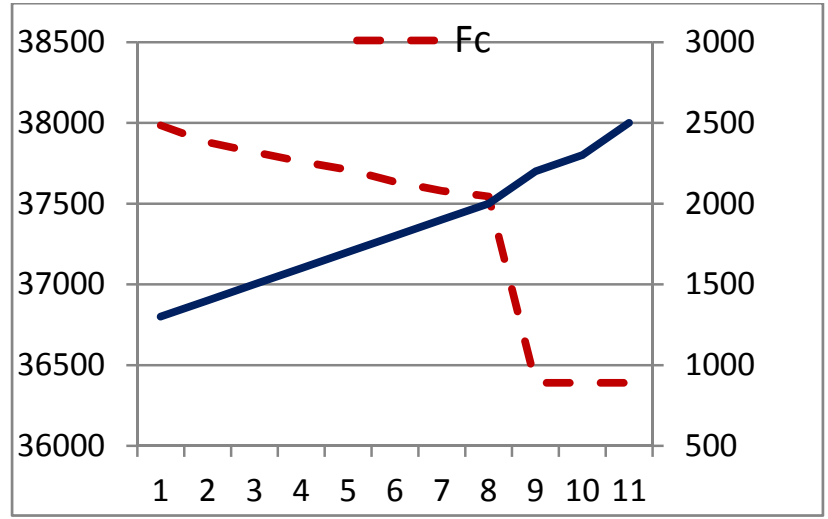

Figure 13. The impact of parameter $\mathrm{V}$ for the solution-stabilization of the solution despite the increase $\mathrm{V}$

That is, the larger the value of $\mathrm{V}$, the smaller the value of the objective function. This happens until the volume reaches a value of about 2100 . Above this value, the objective function does not change and has a minimum value. Additionally, you can determine the use of only one distributor to deliver supplies as confirmed by $\mathrm{P} 4$.

\section{Conclusions}

The paper presents a model for optimizing supply chain costs. Creating the model in the form of a MILP problem undoubtedly facilitates its solution using mathematical programming tools available in LINGO package $^{1}$, in CPLEX ${ }^{2}$ or others. The model should be implemented in one, selected environment package. Implementation of the model in the LINGO package and the computational experiments was presented. The approach from the perspective of optimizing logistics provider that has access to all data and all participants in the downstream chain is very interesting.

After the implementation of the language from the LINGO mathematical modeling package, a number of computational experiments were conducted. Seven of them in the form of examples P1 .. P7 were described in the article. Based on the experimental results, analysis and previous experience, the authors can state that the proposed model and its implementation ensure a very large range of applications. First, they allow finding the distribution flows (decision variables) for the modeled supply chain in optimal or feasible

\footnotetext{
${ }^{1}$ www.lindo.com

${ }^{2}$ http://www-01.ibm.com/software/integration/optimization/ cplex-optimizer/
}

multi-modal network, which minimize the global cost satisfying the needs of customers. Second, they offer a lot of possibilities for decision support in supply chain management through the solutions sensitivity analysis and determination of the range and quality of the effect of various parameters on the cost and even on the structure of the supply chain. The analysis presented in the article, only in terms of the capacity available to distributors and producers fully confirms this statement.

On the one hand, a number of computational experiments show the correctness of the proposed model, on the other hand, they indicate high volumes of calculations that resulted from the nature of the model. This in practice may result in obtaining feasible solutions. Therefore, further work on the presented model and on other models of decision making in the field of supply chain management, manufacturing, etc. will be conducted in two environments. In the first environment we will focus on finding feasible solutions using CLP (Constraint Logic Programming) [23]. The other environment will employ LINGO-type packages for finding the optimal solution based on the results from the first environment. It can be concluded that it would also be multi-modal approach to the implementation and modeling.

\section{References}

[1] Anthony Chavez, Daniel Dreilinger, Robert Guttman, Pattie Maes - A Real-Life Experiment in Creating an Agent Marketplace, http://lcm.csa.iisc.ernet.in/scm/paam97.pdf (accessed 11.09.2012). 
[2] Apt K., Wallace M. - Constraint Logic Programming using Eclipse. Cambridge University Press 2006.

[3] Chavez A., Pattie Maes P. - Kasbah: An Agent Marketplace for Buying and Selling Goods, http://lcm.csa.iisc.ernet.in/scm/paam96.pdf (accessed 11.09.2012)

[4] Chopra S., Meindel P. - Supply Chain Management: Strategy, Planning, and Operation. Prentice Hall of India, 2002.

[5] Connors D., An D., Buckley S., Feigin G., Jayaraman R., Levas A., Nayak N., Petrakian R., Srinivasan R. - Dynamic modelling for business process reengineering. IBM Research Report 19944, 1995, http://lcm.csa.iisc.ernet.in/scm/scm_references.html (accessed 11.09.2012)

[6] Ganeshan R., Harrison T.P. - An Introduction to Supply Chain Management. Department of Management Sciences and Information Systems, 1995.

[7] Handfield R.B. and Nochols E.L. Jr. - Introduction to Supply Chain Management. Prentice Hall, 1999.

[8] Hopp W.J., Spearman M.L. - Factory Physics: Foundations of Manufacturing Management. Irwin, McGraw-Hill, 1996.

[9] Huang G.Q., Lau J.S.K., Mak K.L. - The Impacts of Sharing Production Information on Supply Chain Dynamics: A Review of the Literature [in] International Journal of Production Research, 41(7), 2003, pp. 1483-1517.

[10] Jung H., Jeong B., Lee C.G. - An Order Quantity Negotiation Model for Distributor-Driven Supply Chains [in] International Journal of Production Economics, 111, 2008, pp. 147-158.

[11] Kanyalkar A.P., Adil G.K. - An Integrated Aggregate and Detailed Planning in a Multi-Site Production Environment Using Linear Programming [in] International Journal of Production Research, No. 43, 2005, pp. 4431-4454.

[12] Koźlak A. - Innowacyjne modele biznesowe $w$ prowadzeniu działalności logistycznej [in] Logistyka, No. 3, 2009.

[13] Narahari Y., Biswas S. - Supply Chain Management: Models and Decision Making,

http://lcm.csa.iisc.ernet.in/scm/coimbatore/index.ht $\mathrm{ml}$ (accessed 11.09.2012).
[14] Park Y.B. - An Integrated Approach for Production and Distribution Planning in Supply Chain Management [in] International Journal of Production Research, 43, 2005, pp. 1205-1224.

[15] Perea-Lopez E., Ydstie B.E., Grossmann I.E. A Model Predictive Control Strategy for Supply Chain Optimization [in] Computers and Chemical Engineering, 27, 2003, pp. 1201-1218.

[16] Rizk N., Martel A., D’amours S. - Multi-Item Dynamic Production-Distribution Planning in Process Industries with Divergent Finishing Stages [in] Computers and Operations Research, 33, 2006, pp. 3600-3623.

[17] Schrijver A. - Theory of Linear and Integer Programming. ISBN 0-471-98232-6, John Wiley \& Sons 1998.

[18] Shapiro J.F. - Modeling the Supply Chain. ISBN 978-0-534-37741, Duxbury Press 2001.

[19] Simchi-Levi D., Kaminsky P., Simchi-Levi E. Designing and Managing the Supply Chain: Concepts, Strategies, and Case Studies. McGraw-Hill, ISBN 978-0-07-119896-7,New York 2003.

[20] Simchi-Levi D., P. Kaminsky and E. Simchi-Levi Managing the Supply Chain: The Definitive Guide for the Supply Chain Professional, McGraw-Hill 2004.

[21] Tayur S., Ganeshan R., Magazine M. (eds.) Quantitative Models for Supply Chain Management. Kluwer Academic Publishers, 1999.

[22] Tewari G., Maes P. - Design and Implementation of an Agent-Based Intermediary Infrastructure for Electronic Markets,

http://lcm.csa.iisc.ernet.in/scm/MARI.pdf (accessed 11.09.2012)

[23] Viswanadham N. - Analysis of Manufacturing Enterprises. Kluwer Academic Publishers, 2000.

[24] Viswanadham N., Narahari Y. - Performance Modeling of Automated manufacturing Systems. Prentice Hall of India, 1998.

[25] Walukiewicz S. - Integer Programming. PWN, Kluwer Academic Publishers, Warszawa - Dordrecht - Boston - London 1991. 